\title{
A DOUTRINA HUSSERLIANA DOS ACTOS INTUITIVOS SENSÍVEIS E O TEMA DA CONSCIÊNCIA DO TEMPO
} (1898-1911)

Pedro M. S. Alves

\section{Presentificação e consciência de imagem}

Algumas notáveis deficiências reinam na teoria husserliana dos actos intuitivos expendida nas Investigações Lógicas. Tais deficiências não respeitam a uma eventual incoerência interna da doutrina. Elas não têm sequer que ver com o carácter episódico e disperso dos textos que a apresentam. Essas deficiências dizem antes respeito às decisões teóricas de fundo que conduzem e suportam toda a análise aí efectuada.

De facto, nos textos introdutórios às Lições de 1905 sobre a consciência do tempo, Husserl podia dizer que as diferenças nos actos intuitivos devem ser reconduzidas "às diferenças dos actos em que o tempo se constitui". ${ }^{1}$ Esta asserção pode ser compreendida de um modo trivial como o simples assinalar de que, digamos, percepções e recordaçãos são eo ipso intenções que visam os seus objectos respectivos enquanto presente e enquanto passado. Elas serão, assim, modos de acesso ao temporal. Mas elas supõem, portanto, uma compreensão já disponível do tempo ou, em linguagem estritamente fenomenológica, elas supõem que uma constituição do tempo já se pôs de antemão em marcha num estrato mais profundo. Essa constituição é uma intencionalidade, pois de outro modo não estaria "consciente", mas não é um acto de visar como presente ou como passado, porque então o problema renasceria e abrir-se-ia aquele má regressão ao infinito em que um acto supõe como sua condição ainda um outro acto da sua espécie.

1 "Es scheint fast, während wir bisher unter dem Titel Phantasie Akte befassten, die ein nicht Gegenwärtiges vergegenwärtigen, es nun daran sei, die intuitiven Akt zu definieren, und da müssten wir die Zeitunterschiede finden, oder die Aktdifferenzen finden, in denen sich Zeit konstituiert". Zb., Hua X, p. 394.

Phainomenon, Lisboa, Edições Colibri, 2000, pp. 5-46.

DOI: $10.2478 /$ phainomenon-2000-0001 
A esta luz, a asserção de Husserl pode também significar para lá do seu sentido trivial e imediato - e é justamente isso que começa a desenhar-se com nitidez a partir do curso de 1905 - que a própria diferença entre presente, passado e futuro, a própria abertura original das dimensões do temporal a partir da qual os objectos intencionados podem ser encontrados segundo a sua determinação de tempo, tem a sua raiz na autoconstituição primária do fluxo de consciência e no modo como, por sobre ele, a consciência a si mesma se visa na intencionalidade peculiar da reprodução. Ora que a temporalidade do que é objectual tenha o seu fundamento numa primária autotemporalização da consciência e no modo como ela a si mesma intencionalmente se visa e a si mesma aparece na distância temporal, isso é justamente aquela linha de abordagem que não esteve presente como fio condutor nem nas Investigações, nem por maioria de razão num opúsculo de 1898, dedicado à conexão entre Phantasie e bildliche Vorstellung e à diferença entre percepção e fantasia, que constitui o pano de fundo de todos os desenvolvimentos sobre a questão dos actos intuitivos que ocorrem nas Investigações. ${ }^{2}$

Um dos problemas basilares do ensaio de 1898 é justamente a dilucidação das diferenças internas dos actos pelos quais algo se constitui em geral como intuitivamente dado. A linha de clivagem capital passa entre percepção, como acto originariamente doador, e todas as outras modalidades de actos intuitivos em que a vinda à presença, o dar-se, não tem o carácter da originariedade. Procurando em 1898 determinar esta diferença fundamental que estabelece uma primeira grande linha de clivagem no interior da esfera da doação intuitiva entre o tornar presente ou presentar (Gegenwärtigung) e o re-presentar ou presentificar (Vergegenwärtigung), a decisão de Husserl consiste em pensá-la desde o início a partir da distinção entre percepção e representação figurativa (bildliche Vorstellung), entendida como uma "presentificação em imagem" (Vergegenwärtigung im Bild). ${ }^{3}$

Esse ponto de partida - veremos porquê - não só, a limite, tem um efeito perturbador para a adequada determinação das conexões entre os actos intuitivos (percepção, recordação, etc.), como funciona como uma barreira para que as modulações entre tais actos sejam desde logo interpretadas a partir do fio condutor da consciência do tempo. Mais ainda: essa partição da esfera da doação intuitiva a partir do fio condutor da oposição entre Bild e Sache, entre doação de coisa e doação em "imagem", é o modo como se expressa o relativo alheamento, no ensaio de 1898 que dá a base para as Investigações, entre os problemas

2 Vide "Phantasie und bildliche Vorstellung. Zum Verhältnis zwischen Wahrnehmungs- und Phantasievorstellung" (3.-4. September bis 3. Oktober 1898), P.B.E., Hua XXIII, pp. 108-137. Este opúsculo, em geral ignorado pela crítica, é contemporâneo da redacção das Investigações e tem a enorme vantagem de desenvolver de um modo sistematizado o que elas dizem lacunar e dispersamente sobre os actos intuitivos sensíveis.

3 "Phantasie und bildliche Vorstellung", P.B.E., Hua XXIII, p. 109. 
atinentes à dilucidação dos actos intuitivos e o problema específico da Zeitbewusstsein.

Se a distinção entre dar-se originária e não-originariamente, que divide em dois campos a esfera dos actos intuitivos, pode ser fenomenologicamente justificável, então isso implica a tarefa de encontrar, na esfera variegada da Vergegenwärtigung, uma nota que torne possível agrupar actos cujo teor intencional é tão diverso como a pura fantasia, a recordação ou a expectativa. Fenomenologicamente, uma nota distintiva caracterizadora de toda uma classe de actos não pode ser, prima facie, a mera detecção de uma qualquer característica comum abstractivamente obtida. Se a Vergegenwärtigung pode ser fenomenologicamente entendida como um "género" que encerra toda a variedade dos actos não-presentantes como suas "espécies", então isso significa que todos eles devem ser exibidos como modulações de uma estrutura intencional permanente e subjacente, que os define precisamente como variedades de um mesmo modo do dar-intuitivo que "genericamente" se determina como Vergegenwärtigung ou presentificação. Uma via de acesso para a determinação desse teor subjacente consiste na verificação de que os actos intuitivos que em conjunto caem fora do domínio da consciência perceptiva são certamente actos doadores, mas actos que, nessa doação, não tornam presente em sentido próprio ou autêntico (eigentlich). Este tornar-presente em sentido impróprio (uneigentlich) é precisamente, segundo a caracterização husserliana, a nota distintiva da presentificação. Ele não significa uma diferença no temporal, uma diferença entre visar como agora-presente e, por exemplo, como passado. A doação do que está co-presente, mas não directamente acessível no campo perceptivo circundante, pode ser ela própria um acto intuitivo que é, porém, um acto não de Gegenwärtigung, mas sim de Vergegenwärtigung.

Contudo, com esta determinação genérica não se deu ainda qualquer passo em frente. Ela define a presentificação pela privação do teor de sentido próprio da presentação. Como tal, todos os actos não perceptivos se igualam pelo traçar desta distância relativamente ao dar-se originário. Mas essa caracterização do uneigentlich é ainda impotente para fazer neles sobressair uma estrutura de fundo que os permita encerrar numa mesma classe de actos. A questão é a de saber o que caracteriza a estrutura da presentificação, enquanto ela se vê assim determinada como uma representação intuitiva imprópria, e de que modo os actos intuitivos não-originariamente presentadores podem ser a ela reconduzidos como suas internas modulações.

O "impróprio" no modo da doação não pode desde logo significar a exclusão da esfera da intuitividade, como é o caso das "objectivações impróprias", que delimitam a esfera do pensar signitivo e vazio. "Próprio" e "impróprio" caem antes no interior da esfera intuitiva e devem expressar uma sua interna diferenciação. Na fantasia, algo é intuitivamente representado. Na recordação, também. Mas a consciência doadora não é nem num caso nem noutro uma consciência originariamente doadora. O seu objecto correspondente não está aí 
segundo o modo do "ele próprio originaliter presente". Se nesta impropriedade da presentificação se pode exibir uma nota que a caracterize positivamente, ela tem que ver, segundo a tese de Husserl em 1898 (e também nas Investigações e mesmo para lá), com a circunstância de o intuitivamente representado estar certamente presente, pois de outro modo não se falaria em geral de "intuição", mas está-lo, porém, em imagem, quer dizer, "indirectamente", através de algo que se lhe substitui como propriamente presente e para ele "reenvia":

As representações perceptivas representam o seu objecto como lhes estando ele próprio presente; as representações da fantasia presentificam-no, ao contrário, em imagens da fantasia, tal como as vulgares representações em imagem o fazem em imagem física. ${ }^{4}$

A Bildvorstellung é, assim, a nota genérica da presentificação. E tal significa não só que todas as presentificações contêm como seu elemento estrutural uma "consciência de imagem", como também que as modulações entre a variada gama de actos presentificadores devem ser entendidas e descritas como variações sobre o padrão fundamental da Bildbewusstsein. "Presentificação", como representação intuitiva imprópria, vê-se, assim, genericamente determinada como um vergegenwärtigen im Bilde, um presentificar em imagem.

\section{Estrutura da consciência de imagem}

A dificuldade em encontrar um traço definidor comum às representações intuitivas não-perceptivas parece estar com isto liminarmente superada. Mas na forma decidida como o texto de 1898 pretende resolver a questão da diferença de princípio entre Gegenwärtigung e Vergegenwärtigung esconde-se, todavia, toda uma série de obscuridades que abrem as portas a outras tantas aporias. Pois o im Bilde poderá constituir efectivamente uma adequada caracterização do "impróprio" e do "intuitivo", como notas conjugadas definidoras da "presentificação"? Estar intuitivamente dado de um modo "impróprio", isto é, não-perceptivo, significa eo ipso estar dado numa imagem? Na verdade, que é que "na imagem" está efectivamente dado? Não certamente a própria coisa representada, mas aquilo que a "substitui". Ora é este elemento representante por si só suficientemente potente para caracterizar a presentificação da coisa ainda como uma representação intuitiva? Intuitivamente presente, e mesmo presente em sentido próprio, está indubitavelmente aquilo que aparece como "imagem", ou aquilo que é como tal apreendido. Mas esta presença própria da imagem

\footnotetext{
4 "Wahrnehmungsvorstellungen stellen ihren Gegenstand als ihnen selbstgegenwärtigen vor; Phantasievorstellungen hingegen vergegenwärtigen sich ihn im Phantasiebilde, wie die gewöhnlichen Bildvorstellungen es im physischen Bilde tun". P.B.E., Hua XXIII, p. 109. (subl. nossos).
} 
enquanto tal pode valer ao mesmo tempo como uma presença - "imprópria" ou "indirecta" - da coisa representada, de tal modo que por relação a esta última se possa falar ainda de um acto intuitivo?

Esta é uma primeira dificuldade. Mas uma outra se levanta ainda: o "im Bilde" pode significar já, por si mesmo, outra coisa que a percepção, de modo a que se tenha com ele isolado uma outra classe de actos intuitivos, ou será ele apenas uma complicação interna da própria doação perceptiva, uma complexificação da estrutura interna da Gegenwärtigung? Ao tentar surpreender na consciência figurativa ou de imagem a essência da presentificação abandona-se já, verdadeiramente, o domínio da consciência perceptiva e franqueia-se as portas que abrem para uma nova esfera de actos intuitivos? Os actos presentificadores devem, é certo, estar referidos à percepção como forma fundante. Isso é uma lei de essência fundada nos géneros respectivos. Mas este estar referido à percepção pode significar um simples estar construído sobre a percepção, como parece ser aqui o caso, ao se apresentar a presentificação como consciência de imagem e a estrutura da imagem, por sua vez, a partir da "vulgar [...] imagem fisica", com suporte perceptivo?

A ponderação destas dificuldades apenas pode ser realizada a partir de uma inspecção prévia da estrutura própria da consciência de imagem. A Bildbewusstsein contém, como seus elementos internos estruturantes

(a) uma percepção cousal (sachliche), ou seja, um momento presentativo, no qual se constitui a doação do objecto que "suporta" o aparecer da imagem;"

(b) uma intenção não-preenchida, na qual o "figurado" ou o "original da imagem", o Bildsujet, é expressamente visado de forma representativa (no sentido em que "representação" se opõe à plenitude intuitiva);

(c) o momento figurativo propriamente dito, que une as duas intenções, ou a constituição do Bildobjekt, do "objecto-imagem" por sobre a percepção cousal. $^{6}$

É este terceiro momento que é decisivo para a compreensão da estrutura da presentificação como "representação intuitiva imprópria". Se ele não ocorresse, ter-se-ia na verdade dois actos sem interna ligação. De um lado, o acto que se

5 No caso mais simples, porque são possíveis graus crescentes de complexidade. Por exemplo, a fantasia de uma estátua, de um busto, etc, em vez da sua percepção, ou então a imagem de uma imagem (e. g., a fotografia de uma quadro). Estes casos não trazem nada de novo para a estrutura da Bildbewusstein.

6 "Drei Objekte haben wir: 1) das physische Bild, das Ding aus Leinwand, aus Marmor usw. 2) Das repräsentierende oder abbildende Objekt, und 3) das repräsentierte oder abgebildete Objekt. Für das letztere wollen wir am liebsten einfach Bildsujet sagen. Für das erste das physiche Bild, für das zweite das repräsentierende Bild oder Bildobjekt”. P.B.E., Hua XXIII, p. 19. Cf. o texto paralelo de 1898, p. 109. 
dirige sobre o campo perceptivo circundante disponível e nele releva algo que se destaca contra um fundo de co-doação. Do outro, o acto que se dirige para fora desse campo e visa o seu objecto "no vazio". Ao sobrevir, porém, aquela modificação que faz aparecer o ser-imagem por sobre a doação perceptiva, não só se produz uma íntima conexão entre ambos os actos como, da sua ligação, surge por sua vez um novo acto de estrutura complexa que os altera em conformidade.

Esta estrutura já complexa pode ser aclarada a partir da análise de um exemplo ilustrador. Para nos quedarmos na esfera dos exemplos dilectos do próprio Husserl, tomemos o caso da estátua que ora se olha como coisa física ora como busto de Napoleão. A consciência puramente presentativa é continuada posição do seu objecto e inserção do perceptum na conexão da experiência. Ela é uma unidade de continuada intenção, de Inhaltsverlauf no preenchimento e de progressiva confirmação na posição. Se nela surge o momento figurativo, o modo presentativo da consciência primitiva não se vê com isso alterado. $\mathrm{O}$ núcleo intuitivo apresentante torna-se antes a base sobre a qual se ergue uma nova função de apreensão. Esta dirige-se para outra coisa, para o Bildsujet, e essa função não se substitui à primeira, mas desloca-a para uma posição não-temática. A consciência presentativa torna-se agora um mero momento que suscita a passagem para uma nova apreensão que a encobre. Com esta nova função de apreensão, o complexo de conteúdos apresentantes é agora investido de uma nova função apresentadora, uma função que já não culmina, porém, numa nova consciência posicional, quer dizer, numa consciência do ter-aí como presente numa captação de ser. É esta ausência do momento posicional que transforma esses conteúdos: por eles, não se constitui agora uma coisa na sua presença perceptiva, mas aquilo que justamente designamos como a "imagem". A imagem que aqui se constitui não é, porém, algo "na" consciência. Ela é, muito pelo contrário, algo objectivo. Ela está aí, a imagem aparece em sentido próprio, ela constitui-se, no todo ou em parte, através dos mesmos conteúdos apresentantes que estavam e continuam a estar operantes na percepção primitiva. Só que a aparição da imagem de Napoleão é desde o início uma posição suprimida, ela aparece objectivamente como um nada. ${ }^{7}$ Ela não funda uma nova consciência presentadora que entre em conflito com a percepção inicial. Devido a isso, o que nela aparece é apenas uma abertura ou um puro reenvio para algo, reenvio que, fazendo-se a partir de conteúdos apresentadores, não é equivalente ao reenvio dos signos que sinalizam por convenção. Esse reenvio é construído no elemento da intuição. Ele faz-se, portanto, por similitude, uma similitude que pode ser mais ou menos completa, mais ou menos detalhada, estender-se por todos os conteúdos apresentantes da consciência perceptiva ou

7 Vide a análise clássica em L.U., XIX/1, pp. 458 e sgs, nomeadamente: "Es ist dieselbe Dame, die beiderseits erscheint, und sie tut dies hier und dort mit identisch denselben phänomenalen Bestimmtheiten. Aber auf der einen Seite steht sie als Wirklichkeit vor uns, auf der anderen im Gegenteil als Fiktion, leibhaft erscheinend und doch als ein Nichts" (texto da 2. edição). 
apenas por uma parte. Numa palavra, se sobrevém na consciência presentadora o momento da presentificação, o que assim aparece como objectividade intuitivamente constituída não é "a coisa mesma", mas tão-só "a sua semelhança", e esta semelhança, enquanto "simples imagem", não é nem objecto de uma consciência posicional nem, a fortiori, de uma consciência perceptiva originariamente doadora.

Por força desta constituição objectiva da imagem, o perceptum surge como o lugar de uma abertura sobre uma nova objectividade. A imagem é o ausentar-se do presente e o apresentar-se do ausente. Toda ela vive na convergência destes dois momentos. A intenção que para ela se dirige não está sequer em conflito com a consciência presentativa fundante. O conflito suporia, na verdade, possibilidade da justaposição. Ora a imagem é, segundo a sua natureza, o aparecer de algo que não se encontra no mesmo plano dos objectos da consciência presentadora e que não pode, em consequência, inserir-se como coisa na conexão da experiência perceptiva. Por ela, a intenção representativa dirigida para o Bildsujet encontra agora um certo preenchimento intuitivo. Não um preenchimento autêntico, que ilustre ou confirme propriamente a intenção significativa. Trata-se antes de um preenchimento que se apresenta como o conferimento de uma plenitude intuitiva ao acto, mas que tem, por outro lado, a particularidade de produzir uma "representação intuitiva imprópria", no sentido de por ele não se constitui a doação directa da coisa visada. O que assim intuitivamente aparece é antes uma simples "similitude", algo que, segundo a expressão corrente, "nos faz lembrar" ou "suscita o pensamento de uma outra coisa", e que só aparece objectivamente porquanto produza efectivamente esse reenvio.

É neste fenómeno, aqui exibido na sua estrutura mais basilar, que, segundo Husserl, se pode surpreender a essência da Vergegenwärtigung. A oposição que aqui se estabelece entre Bildobjekt e Bildsujet não se refere, como é visível, a qualquer diferença determinada pelo grau da similitude. Na verdade, a "imagem" não é aquilo em que a similitude não é levada ao grau máximo e perfeito, produtor de uma hipotética "identificação" em que a distância entre ela própria e o seu original seria supostamente suprimida. Tal forma ainda imperfeita de compreender a diferença que se traça entre consciência perceptiva e de imagem não é, de facto, sustentável. E isto porque, sendo a similitude o tipo de reenvio que se estabelece entre imagem e coisa, ela supõe que a imagem tenha sido já constituída com esse sentido. O grau de semelhança não pode apresentar-se, assim, como um critério pré-existente para, entre as apreensões que constituem o aparecer objectivo de algo, determinar de seguida o que aí apareceria com o estatuto de "imagem" e o que apareceria com o estatuto de "perceptivamente presente". Além disso, tal concepção não é sustentável porque, idealiter, é não só possível uma imagem em tudo semelhante ao seu original, como uma imagem em que cada conteúdo apresentante do objecto perceptivo suscitador fosse ao mesmo tempo conteúdo apresentante para a constituição da imagem. Numa tal consciência, o desenrolar dos conteúdos apresentantes seria não só o pro- 
gressivo constituir-se do perceptum no seu ser-dado, mas também e ao mesmo tempo o progressivo detalhar-se do conteúdo intuitivo da imagem. Nada que fosse nota ou propriedade do objecto seria aí excluído do conteúdo objectivo da imagem e, o que é mais, tudo o que surgiria "em imagem" seria "precisamente igual" ao original. No entanto, por mais longe que fosse esta coincidência entre physisches Bild, Bildobjekt e Bildsujet, jamais se produziria uma fusão ou uma identificação, jamais essa similitude completa se volveria numa pura e simples identidade. E tal não poderia suceder porque o essencial para a constituição da imagem não é nem o grau da similitude com o Bildsujet, nem a maior ou menor coincidência dos conteúdos perceptivos com os conteúdos apresentadores do Bildobjekt. O que é essencial para a constituição da imagem é antes o facto de ela surgir objectivamente sob a forma de uma posição cancelada enquanto fenómeno de irrealidade. Não de uma posição que primeiro se exerça e depois se cancele no curso da experiência, mas de uma posição que está, desde a sua origem, neutralizada - "qualitativamente modificada", na linguagem das Investigações -, uma modificação que constitui de entrada o que aí aparece objectivamente como "coisa nenhuma", como luminescência de um puro aparecer sobre o qual se vem edificar uma relação de reenvio. Por via desta última, o que objectivamente aparece "como um nada", quer dizer, o que puramente aparece sem a força e o peso da tese de ser, justamente porque não se firma sobre si mesmo e tem esse carácter volátil do simples scheinen, é transposto para o objecto representado na intenção vazia e confere a esta uma certa plenitude intuitiva. Mas, ao mesmo tempo que se verifica esta transposição, produz-se uma consciência que vai no sentido inverso ao da síntese de identificação cousal produtora da evidência da doação em original. Por sua via dizemos - aquilo que aqui e agora temos diante não é a "própria coisa" em que pensamos, é "apenas" uma sua imagem.

Husserl di-lo na tecnicidade da linguagem fenomenológica:

Em face da imaginação, a percepção é caracterizada por isso que, nela, o objecto aparece "ele próprio" e não apenas "em imagem". Com isso reconhecemos imediatamente as diferenças características das sínteses de preenchimento. A imaginação preenche-se por meio da síntese específica da semelhança de imagem, a percepção, através da síntese da identidade cousal. ${ }^{8}$

Tal é a "representação intuitiva imprópria", como determinação da Vergegenwärtigung. Ela investe uma triplicidade de elementos constitutivos: um momento presentador que se encobre como "suporte" e que só aí comparece

8 "Gegenüber der Imagination ist die Wahrnehmung [...] dadurch charakterisiert, dass in ihr der Gegenstand "selbst" und nicht bloss "im Bilde" erscheint. Darin erkennen wir sofort die charakteristischen Verschiedenheiten der Erfüllungssynthesen. Die Imagination erfüllt sich durch die eigenartige Synthesis der Bildähnlichkeit, die Wahrnehmung durch die Synthesis der sachlichen Identität [...]". L.U., XIX/2, p. 588 (subl. nossos). 
precisamente como encoberto, um puro aparecer segundo a modificação qualitativa que Husserl denomina "simples representação", e uma síntese de similitude que empresta ao visado o carácter do aparecer intuitivo, improprie dicto, porém.

\section{A unidade entre auto-apresentação e presentificação}

Esta tese de Husserl deve medir-se através do acesso aos fenómenos correspondentes, tal como eles se exprimem na compreensão natural, e deve exibir aí a sua pertinência como instrumento de mostração da sua estrutura profunda de sentido. Se queremos ponderar o bem fundado desta decisão teórica de Husserl quanto à essência da presentificação, o critério último só pode ser aqui que a conceptualidade fenomenológica não perverta o sentido desses fenómenos tal como se exprime já na compreensão imediata e não construa, assim, um fictum em seu lugar, em vez de os levar a uma plena explicitação. Voltemo-nos então para uma "imagem" da fantasia. Por exemplo, para a de um livro, a do livro de Edward Gibbon. Produzamo-la, notemos o modo da sua súbita entrada em cena, sem que estivesse já pré-dada numa afecção destacando-se sobre um campo perceptivo de fundo. Notemos como, por assim dizer, "paira" diante de nós, sem que haja nela nenhum ponto de articulação com o campo perceptivo continuadamente dado e sempre disponível. Olhemos o modo como, nela, o livro aparece de uma perspectiva, sob uma certa orientação, e subitamente sob uma outra, numa série descontínua de aparições sucessivas. Notemos ainda como o Ego que fantasia não é aí um puro Ego de observação, mas como ele se insere no mundo fantástico como seu sujeito, como ele tem aí o livro entre mãos, o manipula, como o Ego nesse mundo constantemente vive e age sob o modo do "como se".

Perguntemos então: é esta "imagem" da fantasia uma imagem no sentido preciso da Bildbewusstsein que acabámos de circunscrever na sua estrutura essencial? Manifestamente, a resposta só pode ser uma: se ambas se designam ainda como "imagem", isso deve-se apenas a uma nefasta plurivocidade do termo. Se a natureza da consciência de imagem é o ser uma "representação intuitiva imprópria", indirecta, então a imagem da fantasia só de modo equívoco pode ser ainda denominada como tal. De facto, na fantasia, é o próprio livro de Gibbon que aparece e não outra coisa como seu representante intuitivo - esta figuração é figuração do livro, não a presentação de algo que para ele reenvie por um laço de similitude. É o livro que aí está "como que" presente. Numa palavra, a representação da fantasia tem a estrutura de uma auto-apresentação (Selbstdarstellung): nela, é "a própria coisa" que aparece. A fantasia não está determinada pela consciência de um representante intuitivo intermédio ou de uma imagem, no sentido estrito da Bildbewusstsein.

Este é um ponto melindroso. E é-o tanto mais quanto o texto de 1898 e as Investigações Lógicas no seu todo acabam por sucumbir à tendência para inter- 
pretar a fantasia a partir do fio condutor da Bildbewusstsein. ${ }^{9}$ Há certamente motivos propendendo nesta direcção. Desde logo, o carácter não-originário da representação da fantasia. A fantasia, se não é pura fantasia, mas intenção de uma objectualidade posta numa consciência de realidade, reenvia então para uma consciência presentadora como sendo aquela em que a intenção pode encontrar o seu autêntico preenchimento. A "imagem" da fantasia aparece, assim, como um "substituto" da representação perceptiva. Ela está no lugar deixado em aberto pela sua ausência. Mas fá-lo sem que se lhe possa substituir completamente, pois, na consciência que para ela se volta, está ainda contido um reenvio que a atravessa e põe, para lá dela, a possibilidade de uma consciência perceptiva como lugar onde a intenção propriamente se consuma e satisfaz. Mas tal não significa, contudo, que a representação da fantasia seja já uma representação intuitiva imprópria, no sentido estrito da consciência de imagem. O reenvio para a percepção não é, aqui, em tudo idêntico a que conecta a imagem com o "seu" original. De facto, uma consideração atenta mostra que, na fantasia, o objecto é certamente dado de modo impróprio, mas que essa impropriedade da doação é ainda uma modalidade da auto-apresentação. O livro é dado directamente, ele está presente, se bem que não segundo o modo da Leibhaftigkeit - ele "paira" diante, precisamente à maneira de uma presença "fantasmática" no sentido corrente, a qual é, porém, ainda uma modalidade de autodoação. A consciência do livro na fantasia não é, assim, mediada por um qualquer representante intuitivo, que dele ao mesmo tempo se distinguisse e para ele reenviasse por um qualquer laço de similitude. A síntese de preenchimento tem aqui o carácter de uma verdadeira identificação. Ela produz, se não uma confirmação da qualidade posicional do acto, pelo menos uma efectiva ilustração da sua matéria intencional. O carácter impróprio da fantasia, carácter que justamente a define como presentificação, nada tem, por isso, que ver com a estrutura da Bildbewusstsein. Esta supõe, na verdade, uma consciência originariamente presentadora e, sobre ela, um acto que vise algo em si mesmo distinto do que aí se constitui como objectividade presente "em carne e osso". Esta dupla objectividade ou sobreposição de intenções não se encontra, contudo, na "imagem" da fantasia. Presente está apenas a coisa visada, o livro de Gibbon. Só que essa presença tem aqui o sentido da não-originariedade. Numa palavra, o livro é presentificado, mas essa presentificação é ainda uma modalidade de auto-apresentação.

Só quando esta compatibilidade entre presentificação (Vergegenwärtigung) e auto-apresentação (Selbstdarstellung) passa despercebida é que a identificação entre fantasia e consciência de imagem pode passar como algo compreensível.

9 Por exemplo: "[...] der Synthesis mannigfaltiger Wahrnehmungen, in denen immer derselbe Gegenstand zur Selbstdarstellung kommt, entspricht die parallele Synthesis mannigfaltiger Imaginationen, in denen immer derselbe Gegenstand zur bildlichen Darstellung kommt". L.U., XIX/2, p. 591. 
O passo em falso do texto de 1898 tem precisamente a sua raiz numa situação complexa e quase inextricável: há na fantasia um momento auto-apresentativo, momento que tem que ver com o facto de a coisa fantasiada estar dada "por si própria", segundo o modo da Selbstdarstellung. Se, porém, esta Selbstdarstellung é confundida, como de facto acontece, com a Gegenwärtigung, então ela terá de ser excluída do modo de doação do próprio objecto fantasiado, porque a representação da fantasia, enquanto presentificação, é por definição incompatível com a estrutura da presentação. No entanto, esse momento da consciência de presença "da própria coisa" tem, por outro lado, de ser mantido firmemente, pois ele é um componente inegável da representação da fantasia. Como conciliar estes dois elementos aparentemente contrários? A saída - fenomenologicamente incorrecta - de Husserl para esta dificuldade consiste em desdobrar a fantasia numa dupla objectividade. De um lado, a coisa visada, enquanto é dada segundo o modo impróprio da presentificação, excluirá de si o momento presentativo. Do outro, esse momento passará agora para o lado da "imagem". A consequência impõe-se por si: o momento presentativo da fantasia será assim constitutivo da presença de um Bildobjekt. E a coisa mesma que é visada será compreendida como a consciência intuitiva imprópria de um Bildsujet. O que era uma duplicidade interna da representação da fantasia - presentificação na auto-apresentação - vê-se agora desdobrado em duas objectualidades separadas.

Que tal procedimento seja sumamente problemático torna-se bem visível no facto de a presentificação ser uma modificação da presentação e não uma sua suposta complicação. $\mathrm{O}$ acto presentador não se mantém e combina com outro carácter de acto que visasse "outra coisa" para lá do dado, através de uma síntese de similitude. As modificações que conduzem da presentação às formas diversas da presentificação (fantasia, recordação, expectativa) são todas elas doações "em original" (se bem que não doações "originárias"), e têm a sua origem nos modos da declinação temporal do ser-presente e na eventual neutralização da qualidade objectivante (a "simples fantasia"). Estas últimas diferenças não afectam, porém, o carácter auto-apresentador. Este refere-se apenas ao carácter directo, não-mediado da doação, e tem o seu contraponto naquilo que poderíamos designar como hetero-apresentação, enquanto ela caracterizaria a presença "imprópria", através de um termo intuitivo intermédio, só ele dado como "ele próprio presente".

É o bom entendimento deste ponto que causa uma dificuldade extraordinária no texto de 1898. A razão última desse facto está na omissão do problema do tempo como fio condutor e na sua deficiente substituição pela oposição entre consciência de coisa e consciência de imagem. À oposição presentação/presentificação (cuja raiz é a declinação temporal) vem, assim, sobrepor-se a oposição auto-apresentação/hetero-apresentação (que se firma na dualidade entre mostração directa e indirecta). Elas passam a, funcionar como equivalentes, de tal modo que "presente ele próprio" é agora sinónimo de "dado como presente" 
e, em consequência, "dado como não-presente" (presentificado) passa a significar "presente através de um termo intuitivo intermédio", de uma imagem. Determinando ainda incorrectamente a essência da presentificação a partir da consciência figurativa, a sua oposição à presentação é, em suma, desde o início entendida a partir da oposição entre Bild e Sache. Se a fantasia não é consciência doadora da coisa na sua Leibhaftigkeit, então ela será necessariamente uma presentificação; e se a presentificação, enquanto representação intuitiva imprópria, é consciência da coisa através de um termo interposto, então, assim o estatui Husserl, a fantasia (mas também a recordação e a expectativa) conterá, mutatis mutandis, exactamente a mesma estrutura que a consciência de imagens físicas. O seu carácter comum, enquanto presentificações, será justamente a Bildlichkeit.

É sobre este passo em falso inicial que se precipita todo o texto de Husserl:

Na representação da fantasia, a imagem é seguramente, num certo sentido, o objecto representado; o que é nela propriamente visado é, porém, um outro, uma coisa dela distinta. O Palácio de Berlim não é a minha imagem da fantasia do Palácio de Berlim. ${ }^{10}$

\section{Daí que}

Na representação da fantasia, temos dois objectos apreendidos, a saber, a imagem da fantasia e, produzido representativamente por este meio, o sujeito da imagem: visado, representado em sentido próprio, é, porém, apenas o último. ${ }^{11}$

\section{Generalização do modelo da consciência de imagem}

Uma vez este ponto estabelecido, a dilucidação da estrutura da fantasia como forma da presentificação torna-se, agora, uma simples questão de depuração dos elementos que, na consciência figurativa, pertencem em exclusivo ao momento presentativo da constituição da imagem física.

De facto, na consciência de imagem física tomada como um todo são diferenciáveis três direcções do olhar, que encontram como seu termo outras tantas objectualidades. Há, de um lado, a objectividade perceptivamente constituída, o

10 "In der Phantasie ist zwar das Bild in gewisser Weise vorgestelltes Objekt, aber das in ihr eigentlich gemeint ist ein anderes, eine von ihr verschiedene Sache. Das Berliner Schloss ist nicht mein Phantasiebild vom Berliner Schloss". "Phantasie und bildliche Vorstellung", P.B.E., XXIII, p. 111 (subl. nossos).

11 "In der Phantasievorstellung haben wir zwei aufgefasste Gegenstande, nämlich das Phantasiebild und das hierdurch vorstellig gemachte Bildsujet: gemeint, im eigentlichen Sinn vorgestellt, ist aber nur das letztere". "Phantasie und bildliche Vorstellung", P.B.E., XXIII, p. 112 . 
objecto dado no campo perceptivo e funcionando como suscitador da apreensão figurativa (a estátua como objecto perceptivo). O olhar que sob ele se dirige pode de seguida, mantendo ainda a orientação para o campo perceptivo, constituir a aparição objectiva, no todo ou em parte, como "imagem", pela supressão do carácter posicional (o busto de Napoleão). O que assim "aparece" é algo que é encontrado no campo perceptivo mas já não é inserível na conexão da experiência. A direcção do olhar pode, finalmente, voltar-se para o que é propriamente visado na consciência de imagem, para o "representado" (Napoleão), considerá-lo como termo intencional de uma consciência vazia ou transportar para ele o conteúdo intuitivo da imagem, por meio de uma síntese de similitude. Esta triplicidade da consciência de imagem parece, assim, fornecer a chave para uma cabal determinação da estrutura da fantasia. Basta para tal suprimir-lhe a referência ao campo perceptivo e à objectividade nele presentativamente constituída como objecto suscitador da consciência figurativa. Em harmonia com os seus supostos de fundo, Husserl procede a esta translação em dois passos sucessivos. Primeiro, pela exclusão da objectividade perceptivamente constituída da estrutura essencial da consciência figurativa:

Na direcção que nós até agora explorámos, não se mostra nenhuma diferença interna importante entre representação da fantasia e representação de imagem física. A possibilidade de, na última, ao lado do objecto figurado, distinguir ainda dois objectos [o Bildobjekt e a imagem física] não significa que esta dupla objectualidade [...] pertença ao fundo representativo [repräsentativen Grunde] da representação [Vorstellung]. Também com a representação físico-imagética esta forma representativa estava apenas ligada a um objecto, à imagem representante. ${ }^{12}$

Esta compreensão do objecto suscitador como inessencial para a estrutura da consciência de imagem permite, de seguida, a apresentação da fantasia não só como variante de consciência figurativa, mas como aquela em que esse elemento inessencial está já desde sempre, por natureza, omitido:

A imagem da fantasia está fora de qualquer conexão com a "realidade", quer dizer, com o campo visual da percepção possível. Ao contrário, a imagem fisicamente apresentada está, em certo sentido, incluída na conexão da realidade, se bem que ela própria não valha aí como real. Mais: com a representa-

12 "In der Richtung, die wir jetzt durchforscht haben, zeigte sich kein erheblicher innerer Unterschied zwischen Phantasievorstellung und physicher Bildvorstellung. Die Möglichkeit, bei der letzteren neben dem abgebildeten Gegenstand noch zwei Gegenstände zu unterscheiden, bedeutet ja nicht, dass diese zweifache Gegenständlichkeit [...] zum repräsentativen Grunde der Vorstellung gehöre. Auch bei der physich-bildlichen Vorstellungen war die repräsentative Funktion nur an einen Gegenstand gebunden, an das repräsentierende Bild". "Phantasie und bildliche Vorstellung", P.B.E., XXIII, p. 123 (sub. nossos). 
ção físico-imagética funciona um objecto real, pertencente ao campo visual da percepção, a saber, a imagem física, como suscitadora da apreensão figurativa; a sua percepção é o ponto de partida e de passagem para o desenvolvimento da representação figurativa. À representação da fantasia falta este enlace específico com uma determinada aparição no campo visual da percepção, ela não tem nenhum suscitador. ${ }^{13}$

O que falta à fantasia é, assim, o elemento não-essencial da Bildbewusstsein. A absorção da fantasia pela estrutura da consciência figurativa parece, pois, poder impor-se com naturalidade. Se a conexão com a realidade perceptiva que a consciência de imagem contém é um momento sempre inessencial, a fantasia, de onde essa conexão está por natureza ausente, surgirá em consequência não só como uma forma de consciência de imagem, mas como forma canónica da consciência figurativa.

Há efectivamente na fantasia este elemento presentativo? Constitui-se na fantasia uma aparição objectiva que pode ser considerada por si mesma, abstraindo da função representativa que desempenhe na Bildbewusstsein? É possível distinguir a "imagem" como representante intuitivo e essa mesma imagem como pura aparição objectiva, considerá-la no seu ser-presente, independentemente da função de reenvio? É, em suma, possível considerar a essência da presentificação como o sobrevir de uma nova função de apreensão que transforme uma objectualidade dada como presente num representante intuitivo impróprio de outra coisa meramente visada?

É aqui que o carácter construtivo das análises encetadas aparece em toda a sua amplitude. Este elemento supostamente presentativo outra coisa não é senão o resultado de uma confusão conceptual com o carácter auto-apresentador da fantasia. Não há na fantasia um objecto presente sobre o qual se constitua a consciência de imagem com o seu característico reenvio no elemento da similitude. Este "ser presente" é apenas uma falsa interpretação do facto de, na fantasia, o visado ser dado segundo o sentido da Selbstdarstellung, da auto- e não da hetero-apresentação. Mas o que caracteriza a posição de Husserl é precisamente a circunstância de não recuar diante desta concepção inverosímil e levar a analogia com a consciência de imagem até às suas últimas consequências.

Ora "[...] quando o objecto da fantasia [...] não funciona representativa-

13 "Das Phantasiebild ist ausser allem Zusammenhang mit der "Wirklichkeit", das ist mit dem Blickfeld möglicher Wahrnehmung. Hingegen ist das physisch dargestellte Bild in den Wirklichkeitzusammenhang in gewisser Weise einbezogen, obschon es darin nicht selbst als Wirkliches gilt. Ferner: Bei der physisch-bildlichen Vorstellung fungiert ein zum Blickfeld der Wahrnehmung gehöriger, wirklicher Gegenstand, nämlich das physische Bild, als Erreger der bildlichen Auffassung, seine Wahrnehmung ist der Ausgangs- und Durchgangspunkt für die Entwicklung der bildlichen Vorstellung. Bei der Phantasievorstellung fehlt diese eigenartige Anknüpfung an eine bestimmte Erscheinung im Blickfeld der Wahmehmung, sie hat keine Erreger"."Phantasie und bildliche Vorstellung", P.B.E., XXIII, p. 123 (subl. nossos) 
mente, é ele então um objecto de percepção, correlativamente, é a sua apreensão uma apreensão perceptiva [presentadora]?"14 Eis então a pergunta inevitável. Mas eis também a pergunta a que Husserl não pode já responder satisfatoriamente. Por mor da coerência, Husserl não pode recuar perante a única resposta possível: "se abstrairmos da sua função figurativa, a imagem é um objecto aparecente tanto quanto um qualquer objecto da percepção. De facto, a apreensão, a que devemos este objecto aparecente, é, segundo o seu carácter essencial, com segurança não essencialmente diferente da apreensão na percepção". 15 Mas é a insustentabilidade desta resposta - a única possível, porém - que torna evidente o carácter insatisfatório da aproximação programática da Phantasie/Vergegenwärtigung ao modelo da Bildbewusstsein.

\section{As aporias maiores do modelo da consciência de imagem}

A caracterização husserliana da presentificação oferece, na verdade, o flanco a vários reparos importantes.

Há desde logo o do paradoxo. Ao compreender a presentificação como uma representação em imagem e a constituição da imagem como fundada numa presentação subjacente, a teoria da fantasia restabelece sub-repticiamente a triplicidade de momentos objectuais que era dita pertencer em exclusivo às assim chamadas "imagens físicas", com suporte perceptivo. Na verdade, o esquema presentação-imagem-original não é minimamente alterado. Ele é apenas transposto, de tal modo que o momento fundante da presentação é agora referido não à percepção, mas a uma Phantasieerscheinung que "segundo o seu carácter essencial, [...] não é essencialmente diferente da apreensão na percepção”. As tentativas de Husserl para mostrar a especificidade da fantasia revelam-se, assim, como antecipadamente condenadas a fracassar. Certamente que a imagem do Palácio de Berlim não contém um elemento presentativo a inserir na percepção. Mas se suprimirmos a função representativa contida na imagem do Palácio de Berlim (o reenvio para um original, constitutivo do ser-imagem enquanto Bildobjekt), fica-nos ainda e sempre a consciência presentativa de $u m$ Palácio (na fantasia), que pode dar a base para uma experiência que decorra paralelamente à percepção na assim chamada "pura fantasia". Não só encontramos aí de novo a triplicidade do visado, do objecto-imagem e da constituição presentativa de uma aparição da fantasia paralela à aparição da percepção, como

14 " [...] wenn das Phantasieobjekt [...] nicht repräsentativ fungiert, ist es dann ein Wahrnehmungsobjekt, bzw. ist seine Auffassung eine Wahrnehmungsauffassung?" "Phantasie und bildliche Vorstellung", P.B.E., Hua XXIII, pp. 125-126 (subl. nossos).

15 "Abstrahieren wir von seiner abbildenden Funktion, so ist das Bild ein erscheinendes Objekt sogut wie irgendein Objekt in der Wahrnehmung. In der Tat ist die Auffassung, der wir dieses erscheinende Objekt verdanken, ihrem wesentlichen Charakter nach sicherlich nicht wesentlich verschiedem von der Auffassung in der Wahmehmung". "Phantasie und bildliche Vorstellung", P.B.E., Hua XXIII, p. 113 e n. 6 (subl. nossos). 
estas duas esferas de experiência são identicamente presentativas. Elas decorrem paralelamente, como se de duas esferas autónomas se tratasse - tal é a inevitável conclusão. E todas as tentativas de restabelecer ainda uma primazia para o mundo perceptivo sublinhando o carácter prófugo da pura fantasia em oposição à constância da percepção são puramente empíricas e não contêm nada de essencial. ${ }^{16}$ Idealiter, seria mesmo concebível uma consciência vivendo inteiramente mergulhada na fantasia, uma consciência "onírica", para a qual seriam as relações com o mundo perceptivo que apareceriam como intermitentes e fugidias.

O que falta aqui, contra esta paradoxal elevação da fantasia a experiência autenticamente presentadora decorrendo paralelamente à percepção e tendo o mesmo estatuto que ela, é um estudo em profundidade do modo de constituição do chamado conteúdo primário. Enquanto "sensação" e "fantasma" forem entendidos como quase-objectos que "estão" na consciência e dão a base para certas funções de apreensão, cada um deles fundará um tipo de experiência autónomo e as relações entre percepção e fantasia não poderão ser rectamente estabelecidas. De facto, se aquilo a que chamamos sentir é, segundo o modelo sensualista de que Husserl não se libertou, "ter" um conteúdo "na" consciência e vivê-lo de modo ainda pré-intencional, o fantasma só poderá ser pelo seu lado compreendido como a idêntica "posse" de um outro conteúdo específica ou genericamente diferente, que fundará uma nova experiência paralela, mas de teor de sentido idêntico ao da percepção.

Imergir na fantasia não é, porém, entrar numa "outra" esfera de experiência presentativa. É desenvolver uma experiência sob a forma do quase e do como se. A experiência da pura fantasia é uma quase-percepção, uma quase-crença e uma quase-posição. ${ }^{17}$ Ela pode intensificar-se e desenvolver-se numa experiência paralela afectada pela nota do como se, mas, mesmo aí, a diferença da fantasia relativamente à percepção continua a estar presente no próprio seio da fantasia e a afectá-la no seu todo, pondo-a sob o índice do não-verdadeiro. Mas como dar conta desta dimensão, como dar conta de que a experiência fantástica contém em si mesma uma referência à percepção como lugar autêntico da posição da realidade, se a fantasia é pensada como uma experiência construída sobre conteúdos independentes e autónomos, sobre "fantasmas" que, tomados em si mesmos, já nada têm que ver com a hyle perceptiva?

Isso contém já a segunda razão para a insuficiência desta posição - a da circularidade. À aparição da fantasia e à aparição perceptiva é reconhecido corresponderem consciências efectivamente presentadoras. Mas quando se pergunta por que razão uma e outra essencialmente se distinguem ou por que há

16 Husserl tenta esta discriminação a partir da Flüchtigkeit da Phantasieerscheinung no $\$ 14$ do texto de 1898. Vide"Phantasie und bildliche Vorstellung", P.B.E., Hua XXIII, p. 134-135.

17 A tematização desta dimensão só se encontra nos textos husserlianos da segunda década. Vide, p. e., P.B.E., Hua XXIII, pp. 560. 
entre elas uma brusca solução de continuidade, a resposta tentada por Husserl consiste apenas em estatuir que os conteúdos respectivos deverão ser genericamente diferentes. ${ }^{18}$ Ora quando esta diferença genérica dos conteúdos primários é procurada, todo o texto se silencia e apenas é sugerido que ela deve ser tal "[...] que uns apenas podem entrar em cena como conteúdos presentadores de aparições perceptivas, os outros, apenas como conteúdos presentadores de aparições da fantasia". ${ }^{19}$ A diferença entre os modos de apreensão é remetida para a diferença entre os conteúdos e esta, por sua vez, novamente para a diferença entre os modos de apreensão. A circularidade não poderia ser mais óbvia. Nem mais reveladora. ${ }^{20}$

Há derradeiramente a razão da inversão. Sob o título de "momento presentativo" da consciência de imagem, Husserl descobriu indirectamente a natureza verdadeira da fantasia. A aparição de um Palácio é efectivamente uma Selbstdarstellung, e é apenas isso que a expressão "momento presentativo" pode e deve aqui significar. Fantasiamos um salão real, a roda dos cortesãos, os músicos áulicos e as múltiplas peripécias de uma noite na corte. Tudo isso está dado. E directamente dado. Não certamente segundo o modo da presença em carne e osso ou em original, mas precisamente presentificado. Esta forma de presença é completamente distinta da imaginação, enquanto esta contém uma remissão por termo intuitivo intermédio e uma síntese de similitude entre o dado e o propriamente visado. Na fantasia, vemos um Rei. Não uma imagem que represente um Rei. Mas como todos os desenvolvimentos de Husserl são conduzidos pela ideia de que "presentificação" significa uma representação intuitiva imprópria e que este "impróprio" significa "indirecto", através de uma "imagem", resulta daqui uma singular inversão. O que é a verdadeira natureza da consciência presentificante (a Selbstdarstellung) é posto numa posição secundária e inessencial, a título de momento "presentativo" de uma imagem que não é a coisa visada. A função figurativa da imaginação, a qual, correctamente compreendida, é para distinguir rigidamente da estrutura da presentificação, passa agora a determiná-la completamente - se o que está efectivamente presente não é a própria coisa,

18 "Zwischen Empfindungen und Phantasmen könnte ein grundwesentlicher Unterschied sein, er könnte auf dem Unterschied der Gattung im strengartigsten Sinn beruhen, so wie er etwa zwischen Qualität und Intensität besteht. Dementsprechend wären dann auch die Erscheinung der Wahrnehmung und Phantasie auf zwei wesentlich verschiedene Klassen verteilt". "Phantasie und bildliche Vorstellung", P.B.E., Hua XXIII, p. 128.

19 “"...] dass die einen nur als präsentierenden Inhalte von Wahrnehmungsercheinungen, die anderen nur als präsentierende Inhalte von Phantasieerscheinungen auftreten könnten". P.B.E., Hua XXIII, p. 128.

20 Esta situação aporética está bem espelhada no texto das Investigações: "Ob es zwischen Empfindungen und Phantasmen überhaupt wesentliche deskriptive Unterschiede gibt, ob die gewöhnlich angeführten Unterschiede der Lebendigkeit, der Stetigkeit bzw. Flüchtigkeit u. dgl. zu den Inhalten selbst gehören oder zu ihrer Auffassung: darauf können wir hier nicht eingehen". L.U., XIX/1, p. 525 (texto da 1. "edição). 
então o presentificar deve ser entendido como esse momento representativo através do qual um objecto intuitivamente presente pode reenviar por síntese de similitude para um outro não-presente, e será esse reenvio que passará doravante a determinar a estrutura da presentificação. ${ }^{21}$

\section{Extensão do modelo da consciência de imagem à consciência do tempo}

Partindo da amálgama entre Vergegenwärtigung e Abbildlichkeit, não surpreende que a teoria dos actos intuitivos que visam o seu objecto como não-presente se enrede em dificuldades inextricáveis.

Na verdade, quando Husserl se abeira dos problemas específicos da consciência do tempo a partir da oposição reitora entre o par Wahrnehmung-Gegenwärtigung e o par Phantasie-Vergegenwärtigung, a sua decisão de base consiste justamente em interpretar "a própria temporalidade como uma forma de consciência figurativa". ${ }^{22} \mathrm{O}$ esquema da consciência de imagem, com as suas apreensões sobrepostas, é monotonamente aplicado a este "novo caso" de Vergegenwärtigung, sem que se desenhe a sombra de uma interrogação sobre a legitimidade da sua imediata transposição para o domínio da consciência do tempo. Tudo se passa como se às oposições entre "crença e não-crença", "visar em sentido específico e não-visar", instauradoras da "oposição entre perception [...] e imagination", se tivesse simplesmente de acrescentar a "oposição entre agora e passado-futuro", ${ }^{23}$ de tal maneira que o esquema inicial apenas carecesse de uma maior complexidade para dar conta da estrutura específica da consciência do tempo.

De facto, não há na pena de Husserl a menor hesitação: "a minha concepção é então a seguinte: a recordação vulgar é uma apercepção figurativa, tal como a expectativa". ${ }^{24} \mathrm{O}$ transcurso temporal do recordado, tal como ele esteve outrora presente no fluxo temporal da percepção, está dado na Erinnerungsbild:

21 A pura fantasia e a sua dimensão auto-apresentativa não era um fenómeno desconhecido de Husserl, como o prova este trecho do parágrafo quinto do texto de 1898: "Das Bild interessiert uns nicht als Bild von irgend etwas, sondern für sich, als das so und so erscheinende Phantasieobjekt. [...] Da ist von einer repräsentativen Funktion der Erscheinungen, von einem ihnen anhaftenden Bildcharakter nichts zu merken". "Phantasie und bildliche Vorstellung", P.B.E., Hua XXIII, pp. 118-119.

22 "Die Zeitkichkeit selbst als Form des Bildlichkeitsbewusstsein". Zb., Hua X, p. 160.

23 "Gegensatz von Glaube und Nichtglaube (blosser Vorstellung); gegensatz von Meinen im spezifischen Sinn und Nichtmeinen [...]; gegensatz von perception [...] und imagination; gegensatz von Jetzt, Vergangen-Künftig". Zb., Hua X, p. 170.

24 "Meine Auffassung ist doch folgende: die gewöhnliche Erinnerung ist eine bildliche Apperzeption, so wie die Erwartung", Zb., Hua X, p. 173. "Wenn wir uns an $A$ erinnern, so haben wir eine "Phantasie"erscheinung von $A$, d. i. nach meiner Darstellung eine "bildliche" Erscheinung, die also bei Änlichkeit mit einer Wahrnehmungsercheinung von dieser durch den Charakter der "Bildlichkeit" unterschieden ist". "Erinnerung und Wahrgenommenhaben", P.B.E., Hua XXIII, pp. 194-195. 
Se recordo algo que experienciei ontem, tenho então uma representação da fantasia do processo ontem experienciado, reproduzo com isso talvez todo o processo, consistindo em vários passos sucessivos. [...] Mas enquanto as "representações" têm realmente as suas relações temporais, elas querem também figurar representativamente o processo uno temporalmente decorrente. A relação temporal [actualmente] experienciada, etc., é aqui representação da relação agora não-vivida, mas antes passada. ${ }^{25}$

O problema - melindroso, porém - de determinar o modo como, na apreensão da imagem da fantasia, que é uma aparição agora presente, se pode em geral introduzir a referência a um não-agora, recebe também uma resposta inteiramente estribada na monótona aplicação do modelo da Bildbewusstsein:

Representar um objecto na fantasia é ter presentemente uma aparição que está carregada com o carácter da representação. Por força do mesmo, o objecto aparecente não vale como presente, mas antes como presentificado, a aparição representa-o simplesmente. Mas tal como o objecto aparecente em sentido próprio, o objecto-imagem, funciona como imagem para o objecto intentado, assim existe a priori a possibilidade de apreender também a aparição presentemente dada como uma imagem da outra aparição em que o objecto figurado estava presente; o aparecer-de-tal-e-tal-modo do objecto é uma imagem para o estar-realmente-assim-diante-de-mim do objecto. ${ }^{26}$

O aparecer-agora da imagem vale como representante de um não-agora; e porque esse não-agora é, na recordação, não uma pura ausência temporalmente indeterminada (a blosse Phantasie), mas um outro agora temporalmente localizado, essa "aparição presentemente dada [será] uma imagem de outra aparição em que o objecto figurado estava presente". Mas que poderá significar aqui a expressão "estava presente" senão o reconhecimento implícito de que a recordação não é simplesmente o visar de uma objectualidade, pondo-a num outro

25 "Erinnere ich mich an etwas, was ich gestern erfahren habe, so habe ich eine Phantasievorstellung von dem gestern erfahrenen Vorgang, ich reproduziere dabei vielleicht den ganzen, aus den und den Schritten der Sukzession bestehenden Vorgang. [...] Aber während die "Vorstellungen" ihr Zeitlichkeitverhältnis wirklich haben, wollen sie auch den einen zeitlich verlaufenden Vorgang eben vorstellend abbilden. Das erfahrene etc. zeitliche Verhältnis ist hier Repräsentation für das jetzt nicht erlebte, sondern vergangene". Zb., Hua X, p. 152 (subl. nossos).

26 "Einen Gegenstand in der Phantasie vorstellen, das ist gegenwärtig eine Erscheinung haben, die mit dem Charakter der Repräsentation behaftet ist. Vermöge desselben gilt der ercheinende Gegenstand nicht als gegenwärtig, sondern als vergegenwärtig, die Erscheinung repräsentiert ihn bloss. Aber wie der im eigentlichen Sinn erscheinende Gegenstand, das Bildobjekt, als Bild fungiert für den intendierten, so besteht a priori die Möglichkeit, auch die jetzt gegebene Erscheinung als Bild aufzufassen für die andere, in welcher das abgebildete Objekt gegenwärtig war, das So-und-so-erscheinen des Gegenstandes ist ein Bild für das Wirklich-mir-so-gegenüber-stehen des Gegenstandes”. Zb., Hua X, p. 162 (subl. nossos). 
agora diferente do da putativa imagem actual, mas antes a reprodução dessa consciência perceptiva em que ela foi dada como originariamente presente e, através dela, um ver directo do passado, e precisamente como passado? Olhamos a fotografia do Rei D. Carlos. Imaginamo-la agora. Através dela, visamos uma personagem real que situamos numa duração passada do tempo objectivo. Mas é isso recordar? De modo nenhum. O passado, melhor, o ser-passado do visado não nos está aí dado, e é justamente por isso que não podemos recordar-nos do Rei D. Carlos. A ele, visamo-lo quanto muito como passado, mas visamo-lo sem referência a qualquer consciência originariamente doadora (se excluirmos a intropatia na intersubjectividade). A recordação em sentido próprio só se verifica, contudo, quando a objectividade não é apenas posta "no" passado, mas dada por meio de uma consciência que reproduz uma consciência perceptiva e, nessa reprodução, a põe como decorrida. Numa palavra, recordar é indissociável da consciência de um ter-percepcionado, e este "ter-percepcionado" é, por sua vez, indissociável da autoconstituição da consciência como unidade de uma história pessoal onde já se pôs em marcha a constituição prévia de uma corrente temporal e um processo de sedimentação e acúmulo de sentido. Onde esta dimensão reprodutiva de uma consciência originária está omissa não pode haver também recordação no sentido pregnante do termo.

Que Husserl não tenha deixado de estar atento ao facto de a Erinnerung ser na sua essência um sich erinnern e, daí, o lugar privilegiado de autoconstituição do ipse, é algo que está bem atestado nos textos pertinentes. Mas que esta compreensão mais profunda determine uma completa subversão do aparato conceptual e das distinções fundamentais a partir das quais é pensado o fenómeno da recordação e, por extensão, da Vergegenwärtigung, isso é algo que só paulatinamente será visto com total nitidez. Aproximando-se da recordação a partir da determinação principial da Vergegenwärtigung pela Bildbewusstsein e da Phantasie como forma canónica da Vergegenwärtigung, a recordação só poderia ser coerentemente determinada como uma forma tética de consciência presentificante, e esta consciência presentificante como um fantasiar. A percepção é consciência posicional preenchida que dá o seu objecto como "agora presente", na contemporaneidade do perceptum e do percipere; a recordação é, pelo seu lado, uma presentificação ponente, mas como ela põe o seu objecto num agora diferente do que pertence ao acto de o visar, por aí se distinguem também tempo do acto, "dado" na aparição actual da "imagem" representante, e tempo da coisa visada. Que a recordação não seja, porém, apenas o visar de uma objectualidade como passada através de uma imagem representativa presente, que a recordação contenha no seu estrato mais profundo uma consciência que põe uma outra consciência na unidade de um mesmo fluxo de vivências, isso é algo que Husserl não pôde deixar de ver mas que, ao mesmo tempo, não se podia ainda enquadrar de uma forma harmoniosa na sua compreensão geral da natureza dos actos presentificadores. De facto, a tese da Erinnerungsbild neu- 
traliza completamente o significado da observação essencial - já presente num texto de 1898 - de que, na recordação, é recordado "o meu Eu passado". ${ }^{27}$ Efectivamente, se recordar é ter no presente uma imagem que reenvia para um ausente e um observá-lo através dela, em vez da coincidência entre Ego da recordação e Ego que recorda e da imbricação de duas consciências, é-se uma vez mais reconduzido à concepção de que, no agora, aparece "em imagem" tanto a percepção anterior como o Eu que percepcionou. A clausura no presente, que é justamente o contrário da recordação, é aqui integralmente mantida.

\section{A dissolução do modelo da consciência de imagem}

Ao longo das Investigações, a tese da Erinnerungsbild é admitida sem mais e constantemente usada, sem qualquer interrogação a respeito da sua adequação. ${ }^{28} \mathrm{~A}$ situação compreende-se porquanto se tenha em conta que, à época, a única entrada relevante no terreno dos actos intuitivos tinha sido a operada no texto de 1898, apenas ocupado com a relação entre percepção e fantasia a partir do tema da consciência figurativa. Mas bastará apenas que Husserl, entre 1901 e 1904, se abeire dos problemas específicos da consciência do tempo por força da dilucidação das diferenças internas do fenómeno da presentificação para que a estrutura da consciência de imagem comece a revelar as suas limitações para uma descrição da essência da recordação e, a partir daí, para a determinação da própria essência dos actos presentificadores em geral.

A leitura desses textos é só por si elucidativa a respeito de toda esta situação. A par da utilização do esquema da consciência de imagem, desenha-se progressivamente uma compreensão em profundidade do fenómeno da recordação que acabará por subverter as pressuposições teóricas iniciais. Se bem que uma decisão terminante acerca dessa inadequação não tenha sido aí explicitamente tomada, os textos que para ela propendem são claros e falam por si. Num texto datado de 1904 e que Husserl titulará sintomaticamente como Disputation, o esquema da Bildbewusstsein serve de pano de fundo para a análise que aí se enceta do fenómeno da recordação. A sua asserção inicial, introduzindo o exemplo condutor da análise, é bem reveladora do modo como a consciência recordativa é de entrada identificada com as formas da Bildbewusstsein: "Agora tenho eu as imagens da recordação (imagens da fantasia) do nosso salão". ${ }^{29}$ Mas, à medida que o exame se deixa tocar pela estrutura própria da consciência recordativa, surgem uma série de caracterizações que vêm entrar em choque com o suposto inicial que havia sido posto como princípio orientador de toda a

27 P.B.E., Hua XXIII, Beilage XIV, "Erinnerung und Wahrgenommenhaben", p. 196.

28 E.g.: L.U., XIX/1 e 2, pp. 435, 507, 522-523, 560. Cf. o texto de 1898 , citado na nota anterior, pp. 193-201

29 "Jetzt habe ich die Erinnerungsbilder (Phantasiebilder) von unserem Salon". Zb., Hua X, p. 162 (subl. nossos). 
análise. É efectivamente assim que a tese basilar da representação intuitiva imprópria ou hetero-apresentação se vê subitamente subvertida: "[...] na aparição da fantasia aparece já o objecto [...]"; 30 é ainda assim que o conceito de doação intuitiva em sentido próprio, ou auto-apresentação, se vê consequentemente alargado de modo a conter também a doação do não-presente, e que esse fenómeno de presença intuitiva directa do passado é já timidamente reconduzido a um princípio egológico de auto-unificação: "a representação é agora, por conseguinte, agora tal e tal aparição flutuante com tal e tal flutuante momento cromático, etc. Mas a aparição que aí "paira", ou na qual o objecto paira [...], não é agora, e o Eu que a teve, que a ela estava referido e que é igualmente agora recordado, não é também agora, se bem que seja pessoalmente o mesmo que o Eu actual". 31

Auto-apresentação, reprodução de uma consciência por outra consciência na unidade da síntese egológica - a simples identificação destes dois aspectos conexos é só por si suficiente para fazer ruir a tese da Abbildbewusstsein. Contra a compreensão da Erinnerung como uma consciência presentativa e re-presentativa, cindida numa dupla objectividade, impõe-se agora, paulatinamente, a tese de que recordação não é o simples visar figurativamente de uma objectualidade como passada, mas esse fenómeno, inteiramente diverso na sua estrutura e significado, em que uma consciência visa uma outra consciência na unidade englobante de uma síntese egóica de unidade. A partir daqui, franqueado esse limiar crítico, compreende-se que todas as teses anteriores entrarão em colapso e que, sob o título genérico de reprodução, uma completamente nova dimensão da consciência do tempo se abra também à investigação.

Com efeito, os mui raros estudos que deram alguma atenção às basculações de Husserl a respeito da natureza da Vergegenwärtigung são mais ou menos unânimes em detectar uma mudança teórica a respeito da pertinência do modelo da Bildbewusstsein. ${ }^{32}$ Mas nenhum deles pôs em destaque a relevância decisiva

30 "[...] in der Phantasieerscheinung erscheint schon der Gegenstand [...]". Zb., Hua X, p. 164 (subl. nossos).

31 "Die Vorstellung ist jetzt, also jetzt ist die und die schwankende Erscheinung mit dem und dem schwankenden Farbenmoment etc. Aber die Erscheinung, die da "vorschwebt", oder in der der Gegenstand [...] vorschwebt, ist nicht jetzt, und das Ich, das sie hatte, das auf sie bezogen war, das ebenfalls jetzt erinnert ist, ist auch nicht jetzt, aber personal dasselbe wie das jetzige". Z Zb., Hua X, p. 164 (subl. nossos).

32 Eduard Marbach, na sua introdução ao volume XXIII da Husserliana, faz (p. LV) uma breve alusão a esta mutação, que é de resto uma evidência gritante nos próprios textos de Husserl aí publicados. Ela encontra-se registada, por exemplo, em John Sallis, "L'espacement de l'imagination" (in Husserl, Grenoble, Millon, 1989, p. 81), em Seong Ha-Hong, Phänomenologie der Erinnerung, Würzburg, Königshausen und Neumann, 1993, pp. 56 e sgs., e em Rudolf Bernet, "Einleitung" (Edmund Husserl, Texte zur Phänomenologie des inneren Zeitbewusstseins, Hamburg, Felix Meiner, 1985, pp. XXXII-XXXIII), mas sem que um estudo circunstanciado ponha a descoberto todas as consequências deste modelo e as causas e implicações do seu abandono. Um estudo de resto tão pormenorizado e tão esclarecido como o de M. 
do problema da Erinnerung para essa mutação. E como, segundo pensamos, é a partir dos problemas por ela levantados que a descoberta do estrato último da consciência do tempo sobretudo se fará, a unidade fundamental da problemática de Husserl sobre o tempo viu-se em grande medida substituída pela tese da dupla direcção da investigação, primeiro "objectiva", sobre os actos intuitivos sensíveis, e depois "subjectiva", sobre a autoconstituição do fluxo de consciência. Um texto que, segundo Rudolf Bohem, Husserl inseriu com modificações nas suas "lições" de 1905 é, porém, já uma boa indicação do quanto o fenómeno da recordação joga um papel determinante não só na falência do modelo da Bildbewusstsein, como também na unidade de conjunto das pesquisas husserlianas sobre a consciência do tempo:

Que distingue a consciência do tempo na "percepção" de um processo [...] da consciência do tempo na recordação de algo mais passado? Deveríamos dizer: no último caso, no caso da memória no sentido habitual, seria dada uma aparição [...], de tal modo que toda esta temporalidade "presente" é representante, imagem para uma temporalidade passada? De certo modo, acontece certamente figuração, ou em todo caso representação. Mas não há nenhuma consciência figurativa em sentido autêntico [...]. Isto é, eu não tomo a melodia agora decorrendo na consciência recordativa actual como algo de outro em face da melodia recordada, mas, ao contrário, na primeira eu recordo a segunda. Ou mais precisamente: não é aqui como no caso de uma fotografia, onde um similar, porém diferente quanto ao conteúdo, serve de representante para um similar [...]..$^{33}$

Que "na primeira eu (me) recorde da segunda", melhor, que, na primeira, recorde o meu eu da segunda e esteja aí numa imediata unidade de coincidência com ele, tal significa, em última instância, que a vivência original está disponível como estrato sedimentado "em mim" para o acto actual da recordação e que, em suma, a consciência não é imersão no agora-actual da presentação, mas

M. Saraiva (L'imagination selon Husserl, Den Haag, Martinus Nijhoff, 1970) passa surpreendentemente por cima desta clivagem essencial, não sendo sensível a essas mutações que, não estando ao tempo directamente patentes nos textos do vol. XXIII da Husserliana, eram porém já evidentes nos textos de Zeitbewusstsein, de Ideen I e mesmo nas alterações introduzidas por Husserl no texto da 1. ${ }^{\text {a }}$ edição das Investigações.

33 "Was unterscheidet das Zeitbewusstsein in der "Wahrnehmung" eines Vorgangs [...] von dem Zeitbewusstsein in einer Erinnerung an ein ferner Vergangenes? Sollen wir sagen: es sei im letzteren Fall, dem Fall des Gedächtnisses im gewöhnlichen Sinn, eine Erscheinung gegeben [...] derart, dass diese ganze "gegenwärtige" Zeitlichkeit Repräsentant ist, Bild für eine vergangene Zeitlichkeit? In gewisser Weise findet sich Abbildung oder jedenfalls Repräsentation statt. Aber es ist kein Bildlichkeitsbewusstsein im echten Sinn [...]. Nämlich ich fasse die jetzt ablaufende Melodie im jetztigen Erinnerungsbewusstsein nicht als ein anderes gegenüber der erinnerten Melodie, sondern in jener erinnere ich diese. Oder genauer: Es ist nicht, so wie im Falle einer Photographie, wo ein Ähnliches, aber doch inhaltlich Verschiedenes, für ein Ähnliches als Repräsentant dient [...]“. Zb, Hua X, pp. 179-180 (subl. nossos). 
antes o lugar da abertura e da confluência dos tempos. E é esta possibilidade de um transpor-se para o passado que despoleta os problemas mais profundos da constituição prévia de uma corrente de consciência. Firmado nesta doação directa do passado que aqui se desenha já, o texto imediatamente sequente, mesmo sem inquirir da sua possibilidade, tirará deste ponto todas as devidas ilações: "no recordar, o objecto é também representado como ele próprio presente [...], o recordar é também um percepcionar [...]", quer dizer, uma Selbstdarstellung, antes confundida com a Gegenwärtigung; "a representação perceptiva é autopresentificação no sentido do agora, a representação recordativa, autopresentificação no sentido do passado [...]"; "na recordação aparece também o próprio objecto [...], mas ele dá-se precisamente como "aparição" do objecto, como presentificação; é uma representação, mas através da identidade", e não por meio de uma qualquer sintese de similitude entre imagem e seu original. ${ }^{34}$

\section{Consciência de imagem e percepção}

Antes que a reflexão sobre a estrutura da Erinnerung tivesse começado a produzir os seus resultados dissolventes, tudo se passava como se Husserl, partindo do indisputado primado da percepção, tivesse sido conduzido a uma exclusividade do modelo da consciência perceptiva na dilucidação da estrutura dos demais actos intuitivos.

De facto, o modelo da consciência de imagem que aqui se pretende guindar à posição de princípio de compreensão dos actos intuitivos não perceptivos, se observado na sua génese, outra coisa não é senão uma extensão do modelo perceptivo e uma sua complexificação. A génese desse modelo a partir de uma reflexão sobre a estrutura da percepção é, aliás, fácil de documentar a partir dos próprios textos de Husserl. Que se tenha apenas em conta o bem conhecido trecho a respeito do fenómeno do engano (Täuschung) que, nas Investigações, desempenhava um papel importante quando se tratava de avaliar o tipo de conexão entre matéria intencional e qualidade posicional no seio de um acto perceptivo. ${ }^{35}$

O exemplo, aliás recorrente, era aí a oscilação entre duas percepções conflituais, sob a forma de uma variação do als was da apreensão de uma idêntica aparição objectiva. Visitando o museu de figuras de cera, acontece, desprevenidos, interpretarmos a aparição presente como "uma senhora que nos acena". Mas eis que esta apreensão quase se suspende e entra em conflito com uma

34 "Im Erinnern ist das Objekt auch selbstgegenwärtig vorgestellt [...], das Erinnern ist auch ein Wahrnehmen [...]"; "Wahrnehmungsvorstellung ist Selbstvergegenwärtigung im Sinne des Jetzt, Erinnerungsvorstellung Selbstvergegenwärtigung im Sinne des Vergangen[...]"; "In der Erinnerung erscheint auch der Gegenstand selbst [...] aber er gibt sich eben als "Erscheinung" des Gegenstandes [...] als Vergegenwärtigung, est is eine Repräsentation, aber durch Identität". Zb., Hua X, respectivamente pp. 182, 183-184 e185-186 (subl. nossos).

35 Vide L.U., XIX/1, pp. 457-461. 
outra em que essa mesma aparição é interpretada como "figura de cera". A oscilação entre as duas apreensões contrastantes perdura por um lapso de tempo. Ela não incide apenas sobre os conteúdos a cada momento presentes, sobre as aparições momentâneas posteriores ao surgimento do conflito, mas transporta-se sobre a cadeia de aparições passadas retencionalmente conservadas. Olhamos como "figura de cera" a aparição presente. Esse sentido de apreensão transporta-se para a cadeia retencional e reinterpreta-a em conformidade, a tal ponto que a decisão do conflito pode mesmo nascer desse olhar retrospectivo. Seja como for que a resolução do conflito se verifique, e as possibilidades são inúmeras, quando ela ocorre, uma das apreensões conflituosas é cancelada e volve-se numa simples aparência. A "senhora que me acena" continua, bem entendido, a aparecer objectivamente, mas, desde que o conflito se decidiu no sentido da "figura de cera", ela, diz Husserl no mesmo texto das Investigações, aparece doravante como um nada, isto é, ela aparece naquela modificação da qualidade do acto que Husserl, ao tempo, designa como "simples representação". ${ }^{36}$ Ela como que "está â̂" diante de nós e, não fosse a solução do conflito continuar a agir como estrato sedimentado para todas as apreensões subsequentes, depressa cederíamos de novo à mesma ilusão.

É justamente deste fenómeno que se retira essa estrutura da consciência de imagem que é catapultada a forma de fundo da Vergegenwärtigung. Quando a oscilação se decide e é suprimida pela posição firme de um dos seus membros, o fenómeno na sua complexão de conjunto adquire também um novo teor. A sua estrutura dual pode não ser suprimida. Suprimida é certamente a oscilação entre duas percepções concorrentes. Mas a partir do momento em que tal se verifica, o outro membro alternante pode ser ainda mantido e desempenhar agora um novo papel. Olhamos a aparição objectiva e interpretamo-la doravante enquanto "figura de cera". Mas essa mesma aparição, melhor, o manequim que está perceptivamente presente numa belief-Bewusstsein, funciona agora como "imagem" de uma senhora, ele é algo que mostra ou que dá a ver outra coisa que aparece segundo o tipo de presença essencialmente diferente e amputada de qualquer conexão com o campo perceptivo circundante constantemente mantido na forma da posicionalidade. A entrada em cena da "senhora que me acena" é, a partir do momento em que a percepção se estabiliza e o conflito se dissolve, uma aparição cuja posicionalidade está à partida cancelada; a senhora aparece, mas ela aparece de um modo puramente estético, "em imagem", sem qualquer concurso de uma consciência posicional. Se a este puro "aparecer em imagem", a este puro scheinen, se vem agora juntar uma consciência posicional que tome o que assim aparece com referência a uma possivel aparição perceptiva, se à forma não-posicional do puro aparecer em imagem se junta o visar de um objecto como "original" que pode ser encontrado na conexão da experiência perceptiva, então a imagem adquire agora uma estrutura de reenvio fundada numa 
síntese de similitude. Numa palavra, a continuada aparição objectiva da "senhora que me acena" com base na percepção ponente da figura de cera representa agora o surgir de uma doação intuitiva imprópria, fundada não numa síntese de identidade cousal entre conteúdo apresentante e objecto aparecente, mas numa síntese de similitude entre "imagem" e seu "original".

A incorrecção deste esquema para a determinação da essência da Vergegenwärtigung é já visível no facto de, a fim de comparar a "imagem" (presente) com o seu "original" (ausente), se ter de produzir a doação intuitiva do original. Ora esta, como doação directa ou auto-apresentação do não-presente, deverá ser, então, a forma autêntica da presentificação. Directamente haurido na estrutura da consciência perceptiva, este modelo é por Husserl transposto sem mais para toda a gama dos actos presentificantes. Daí essa errónea equação entre fantasia e

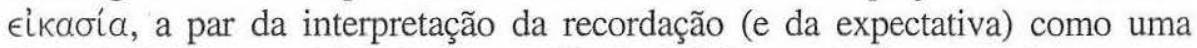
fantasia icónica posicional. A consciência icónica ou de imagem via-se transposta para a fantasia, vimo-lo, através da supressão do elemento perceptivo suscitador. A fantasia, como consciência icónica, seria então uma aparição que entraria em cena imediatamente como Bildobjekt, ao passo que a imagem "física" seria inversamente uma percepção que poderia de seguida sobrecarregar-se com o reenvio da imagem. Mas tanto no interior da fantasia como na consciência de imagens físicas, poderia ainda acontecer que o Bildsujet não fosse apenas representado numa consciência não-posicional como a pura e simples aparição de algo "em" imagem, mas efectivamente posto como realidade existente e originariamente doável num "outro" presente, a distinguir do presente actual em que se constitui a sua imagem - tal seria justamente a essência da recordação e da expectativa.

Que não se tenha com isto franqueado o limiar da percepção, isso é evidente no facto de a própria fantasia conter, como estrato subjacente e fundante, um momento presentador, justamente aquele que Husserl caracteriza como a aparição da imagem presente, abstracção feita da sua estrutura de reenvio. O que funciona aqui como um óbice à entrada no domínio dos actos intuitivos não-perceptivos é, assim, essa tese de que toda e qualquer Vergegenwärtigung tem como base implícita ou explícita uma Gegenwärtigung, uma consciência originalmente presentadora, chame-se o conteúdo presentante "sensação" ou "fantasma", chame-se a aparição objectiva correspondente "aparição perceptiva" ou "aparição da fantasia". Com isso, toda a representação do tempo, que se faz por extensão deste modelo, se vê encerrada no presente de cada vez actual. Mas nem a constituição do presente nem a constituição dos horizontes de tempo foram ainda por si mesmos dilucidados. Eles estão certamente presentes e são constantemente investidos na descrição, mas figuram aí sob o título de algo que é simplesmente pressuposto, sem fornecer ainda o tema para uma correspondente análise constitutiva.

Precisamente considerada, porém, a presentificação não é um acto que vise o seu objecto a partir de um outro objecto presente, mas um acto que visa - e 
dá, intuitiva e directamente - o seu objecto enquanto não-presente. É a ponderação deste aspecto que causa uma dificuldade extraordinária. Como, uma presença do não-presente? Como, no agora, a presença de um outro agora? Tal é, no entanto, a fantasia. Tal é a recordação.

\section{Reorganização husserliana da doutrina dos actos intuitivos}

A entrada em profundidade no fenómeno complexo da Erinnerung é a linha por onde passa quer a libertação husserliana relativamente à equação entre presentificação e consciência de imagem, quer a entrada decidida dos problemas da Zeitbewusstsein na questão relativa à diferenciação entre Gegenwärtigung e Vergegenwärtigung. E a sua entrada não é, como ficou vincado, a mera verificação anódina de que a percepção é doação do "presente", a recordação, doação do "passado", ou o aparecer como presente e como passado das objectualidades correspondentes. Tal entrada em cena dos problemas da Zeitbewusstsein é o anunciar-se de uma linha de reflexão que, pelo tema da Reproduktion, localiza a presentificação no acto pelo qual uma consciência visa o seu objecto através da densidade de uma outra consciência e, no esclarecimento da própria possibilidade desse acto, se vê envolvida num movimento de aclaração regressiva que a conduzirá ao tema da "subjectividade absoluta", ultimamente constitutiva da temporalidade de todo o vivido. A unidade até aqui prevalecente do conceito de imaginação vê-se, com isso, definitivamente quebrada. Ela estava suportada por um equívoco. ${ }^{37}$ Pois o que, em geral, é tido em vista na expressão vaga de "imaginar" (einbilden, abbilden) acolhe fenómenos com estruturas radicalmente diversas e irredutíveis a um paradigma comum.

Essa descoberta da não-unidade do conceito fenomenológico de "imaginação" não é uma Erfindung, uma simples construção que perverta aquele sentido unitário que, na vida imediata, se expressa na utilização da voz comum "imaginação" para nomear uma diversidade de fenómenos pretensamente aparentados. De facto, a imago é simultaneamente abertura e barreira. Nela irrompe o "mundo" de imagem. Mas porque esse mundo é mundo simplesmente observado, mundo apenas dado enquanto visto, a vida penetra nele unicamente sob a forma de um assistir que não se pode de seguida volver num imergir, num tomar parte e num encontrar-se aí. O mundo de imagem tem esta estrutura paradoxal de apenas poder ser aberto no olhar, mas sê-lo de tal forma que deixa às suas portas a vida que assim o constitui, como se ela lhe fosse inessencial. Mas todos os actos que se vêm agora, em oposição à imago, agrupar no conceito autêntico

37 Não nos parece, pois, de aceitar o suposto de M. M. Saraiva no seu estudo pioneiro e até hoje inexcedido sobre "a imaginação": "[...] nós pensamos que a reunião das duas espécies de consciência imaginante sob a designação genérica de imaginação é própria de Husserl $[\ldots]^{\text {" }}, A$ Imaginação segundo Husserl, Paris, Fundação Calouste Gulbenkian, 1994, trad. de I. Támen e A. P. Mesquita, p. 71. 
de presentificação são actos em que não só algo é aberto num "ver", mas actos em que a vida se inscreve no visto, se reencontra a si mesma nele, e isso de tal maneira que, para todos eles, o essencial não é tanto o puro ver com os seus níveis de clareza (que podem ir mesmo até à completa obscuridade) e sim esse transpor-se ou esse "estar por dentro", em que a vida se descobre como vida $\mathrm{em}$ conexão.

Isso é já um elemento da pura fantasia. Ela não é o simples fazer desenrolar como numa cena um espectáculo que se dá simplesmente a ver. Fantasiar, abrir o mundo fantástico, é eo ipso encontrar-se nele como Ego da fantasia, identificar-se com esse Ego e ver o mundo fantástico a partir dessa coincidência, é, em suma, pôr-se em interacção com esse mundo, como alguém que aí está, nele age, nele percepciona, recorda, espera, e assim se tem como centro do mundo fantasiado. "Imagino-me" numa praia, vejo-me passeando, sou eu quem espera o sol nascente, quem aguarda o esclarecer da aurora. O que a compreensão comum adianta sob o título de "imaginar-se" é, pois, outra coisa que um simples olhar que se dirige para uma imago e um ter-se na distância como puro Ego de observação. "Imaginar-se" é "hineinleben". E a mesma estrutura geral é visível nos fenómenos da recordação e da expectativa. Eles não são o puro ver de um não-presente a partir de um constituir presentador. Eles são este mesmo transpor-se, mas um transpor-se que não tem já a liberdade da fantasia por via da introdução de uma referência tética a uma outra consciência real, seja ela passada ou meramente antecipada. Transponho-me para o jardim em que ontem passeei, na recordação, encontro de novo o lago, estou aí; salto agora até ao momento em que descerei a escada úmbrea, encontro-me por antecipação abrindo a porta da rua, sinto o jorrar da luz quente do Verão. Na pura fantasia, mas também na recordação e na expectativa, o elemento de fundo que lhes dá unidade como classe de actos é, portanto, aquela estrutura geral que Husserl isolou sob o título de reprodução (Reproduktion ou simplesmente Erinnerung, lato sensu) de uma consciência por outra consciência na unidade de uma corrente unitária de experiência. A essência da presentificação é, assim, a reprodução, não a Bild. Actos reprodutivos, "recordativos" em sentido alargado, são todos aqueles em que uma consciência originariamente doadora (no caso mais simples) é recuperada, construída ou antecipadamente "reproduzida" e, por essa via, são justamente presentificadas as objectualidade que nela estão originariamente presentadas, mas presentadas por referência a mim mesmo, como vida que originariamente experiencia.

Se a análise dos actos presentificadores se deixa guiar pela estrutura da consciência reprodutiva, encontrará, assim, aquele impulso de fundo que conduz Husserl a tratar a diferença entre presentação e presentificação a partir do fio-condutor da consciência do tempo e à descoberta do fluxo da "consciência absoluta", constitutiva de toda a temporalidade, a qual já não é ela própria um "processo" no tempo. E isto não é uma simples informação sobre a vida contingente de pensamento de um autor. Ela pertence antes aos próprios dados do 
problema. Pois só o centramento na estrutura da reprodução permite tomar a vida de consciência na plena complexidade das suas estruturas e implicações intencionais, só ele permite compreender que a presentação se insere num tecido de reproduções, as reproduções, numa auto-objectivação temporal e nas formas como o ser-temporal da consciência para si mesmo se constitui como tal. E só esse ângulo de ataque do problema geral dos actos intuitivos permite, finalmente, não só dissolver a análise primeira da percepção que tomara forma no esquema sensualista apreensão-conteúdo de apreensão, como também exibir a forma primitiva de constituição do mundo enquanto correlato global da vida de consciência.

Na verdade, há no pensamento de Husserl deste período uma série de anéis concêntricos que as mais das vezes não são claramente apresentados na sua íntima conexão. Nomeadamente, a relação estreita entre, de um lado, os problemas da Zeitbewusstsein e dos actos intuitivos e, do outro, entre o problema dos actos intuitivos "de grau mais baixo" e as questões atinentes a uma fundação última dos actos objectivantes de "grau superior", tratados já nas Investigações sob a rubrica de uma Urteilslehre e da constituição categorial na dupla direcção da "abstracção" formalizante e generalizante. Desse modo, as linhas convergentes que passam, no pensamento de Husserl, entre uma Urteilslehre e uma Wahrnehmungslehre, e entre os actos intuitivos e a Zeitbewusstsein, são postas simplesmente em paralelo, sem que uma conexão íntima entre elas possa ser claramente estabelecida e sem que a unidade do problema possa ser, portanto, restitituída ${ }^{38}$ Contra a mera justaposição dessas linhas falam já, todavia, as expressas declarações de Husserl nos anos imediatamente sequentes às Investigações. Na verdade, já no texto de apresentação do curso de 1904/05 dedicado à fenomenologia dos actos intuitivos de base se pode encontrar a seguinte declaração preliminar:

Como tema das lições que por este meio abro, anunciei: "Elementos Capitais da Fenomenologia e da Teoria do Conhecimento". Originalmente, tinha em vista com isso apenas os actos intelectivos superiores, a esfera da assim chamada "teoria do juízo". [...] Com o estudo preparatório das correspondentes

${ }^{38}$ Esta conexão foi, porém, bem indicada por E. Marbach: "Indem Husserl 1904/05 sich wiederum diesem Weg zuwandte und ausführliche Analysen über Wahrnehmung, Pantasie, Zeit durchführte, kam er tätsachliche über das im Werk von 1900/01 explizit behandelte "Ideengebiet" hinaus; er erweiterte es in Richtung der Fundierung der "höheren intellektiven Akte" des Bedeutens und Urteilens in den "schlichten, zuunterst liegenden intellektiven Akte"'. Hua XXIII, "Einleitung des Herausgebers", pp. XXXV-XXXVI (subl. nossos). O seguinte texto de 1920 estabelece, aliás, claramente o papel de último fundamento que uma fenomenologia dos actos intuitivos desempenha perante uma "ciência do logos" (Wissenschaft vom Logos): "Die Wahrnehmung und ihre paralellen Bewusstseinsweisen der Anschauung sind aber die ersten Grundgestalten des Bewusstseins, die für den Aufbau des spezifisch logischen Bewusstseins in Frage kommen, sie sind erste Grundlagen im logischen Bau, die gelegt und verstanden werden müssen". A.P.S., "Bewusstsein und Sinn - Sinn und Noema", Hua XI, p. 319, n. 1. 
matérias, logo compreendi, porém, que não apenas razões pedagógicas, mas acima de tudo razões substantivas exigiam um minucioso tratamento dos actos intelectivos simples, que jazem na última base. Refiro-me aqui, naturalmente, àqueles fenómenos que, sob os títulos algo vagos de percepção, sensação, representação da fantasia, representação figurativa, recordação, são de todos bem conhecidos e que, todavia, estão ainda muito pouco investigados cientificamente. ${ }^{39}$

\section{O "grande desiderato" (grosses Desiderat) de uma teoria do juízo reconduz} a uma fenomenologia dos actos intuitivos ditos "sensíveis", segundo a voz tradicional e corrente. ${ }^{40} \mathrm{E}$ isso porque só tais actos intuitivos são aquela "última base" de que as formações da consciência judicativa carecem. Que a questão do tempo tenha, na fenomenologia, a sua radicação original no problema da descrição e discriminação do teor fenomenológico dos actos intuitivos sensiveis (percepção, recordação, etc.), e que o próprio complexo de temas fenomenológicos que caem sob os títulos Wahrnehmung-Erinnerung-Bildbewusstsein seja primeiramente induzido pelos problemas relativos a uma teoria do juízo tal como foram expostos nas Investigações, isso advém directamente da necessidade de procurar não apenas a fundação dos núcleos materiais primitivamente simples dos actos proposicionais, mas de fazer da própria evidência a eles relativa $a$ forma basilar da eclosão do mundo como horizonte global a que estão ultimamente referidas todas as objectualidades categorialmente formadas. ${ }^{41}$

39 "Als Thema der Vorlesungen, die ich hiermit erröffne, habe ich "Hauptstücke aus der Phänomenologie und Theorie der Erkenntnis" angekündigt. Ursprünglich hatte ich dabei nur die höheren intellektiven Akte ins Auge gefasst, die Sphäre der sogenannten "Urteilstheorie". [...] Bei der vorbereitenden Durcharbeitung der einschlägigen Materien sah ich aber bald ein, dass nicht bloss pädagogische, sondern vor allem sachliche Gründe eine ausführliche Behandlung der schlichten, zuunterst liegenden intellektiven Akte erfordern. Ich meine hier natürlich jene Phänomene, die unter den etwas vagen Titeln Wahrnehmung, Empfindung, Phantasievorstellung, Bildvorstellung, Erinnerung allbekannt und doch wissenschaftlich noch viel zu wenig durchforscht sind". F I 9/4a-b, apud Rudolf Bohem, Einleitung des Herausgebers a Hua X, p. XV (subl. nossos).

40 Sobre a "Urteilstheorie" como "grosse Desiderat, wofür ich schon so viel gearbeitet habe", ver E.L.E., "Persönliche Aufzeichnungen", Hua XXIV, p. 446.

$41 \mathrm{Na}$ literatura especializada, há uma assinalável flutuação no que respeita à apreciação da conexão que intimamente vincula, na fenomenologia nascente, as questões de uma teoria do juízo, por um lado, e dos actos intuitivos sensíveis e da consciência do tempo, por outro. É assim que, relativamente à relação entre actos intuitivos e Zeitbewusstsein, Mohanty afirma que "The researches into perception and phantasy were connected to, and determined by, Husserl's continuing researches into the nature of our experience of time" ("The development of Husserl's thought", The Cambridge Companion to Husserl, Barry Smith e David W. Smith, New York, Cambridge University Press, 1995, p. 60). Esta declaração, se é correcta no modo como estabelece uma estreita interconexão entre as investigações sobre actos intuitivos e consciência do tempo, é porém inexacta quando sugere que a abertura dos problemas relativos aos actos intuitivos de base tenha sido pré-determinada pelas "continuadas investigações acerca da natureza da nossa experiência do tempo". Na verdade, a situação é precisamente a inversa: 
Esta recondução representa um alargamento (Erweiterung) da problemática original relativa a uma "ciência do logos". A conexão entre a teoria do juízo e a fenomenologia dos actos intuitivos de "grau mais baixo" (sem formação categorial) é, tal como ela se expressa no texto husserliano das Investigações, a problemática da fundação, ${ }^{42}$ e a ideia reitora, uma ideia que só paulatinamente toma forma no pensamento de Husserl e que se viria finalmente a cristalizar nas teses de uma pré-doação (Vorgegebenheit) do mundo e de uma experiência ante-predicativa (vor-prädikative Erfahrung), a ideia reitora é aí que a operatividade da consciência predicativa supõe uma evidência primeira na qual, sem intervenção de qualquer forma da espontaneidade sintético-categorial, acede à doação pela consciência perceptiva e suas modificações um horizonte unitário de objectividades individuais que dão de seguida os "substratos últimos" para toda a enformação categorial e para toda actividade da consciência judicativa. ${ }^{43}$

Husserl aborda os problemas do tempo a partir de um complexo anterior de problemas relativos à intuição e, simultaneamente, essa nova positio quasstionis determina alterações substanciais na caracterização da natureza dos actos intuitivos e na descrição das relações entre as suas várias espécies. Se bem que a exposição deste ponto constitua o objectivo específico dos próximos desenvolvimentos, seja apenas, a título ilustrativo, tida em conta esta declaração expressa de Husserl: "Einige, noch recht unvollständige Versuch zur Behandlung der hierher gehörigen Probleme [dos actos intuitivos] habe ich im zweiten Bande der Logischen Untersuchungen mitgeteilt. [...] Bei einer neuerlichen Durchsicht meiner alten Entwürfe finde ich so manche Gedankenreihen, die in meinen Logischen Untersuchungen nicht zu ihrem Recht gekommen sind, manch wesentliche Schwierigkeiten, die ich damals schon diskutiert hatte, sind in meiner Publikation kaum berührt und nicht weiter verfolgt worden. Ja die ganze Sphäre der Erinnerung und damit auch die gesamten Probleme einer Phänomenologie der originären Zeitanschauung sind darin sozusagen totgeschwiegen. Die ausserordentlichen Schwierigkeiten, die hier liegen, vielleicht die grössen in der ganzen Phänomenologie, vermochte ich nicht zu bewältigen, und da ich mich nicht im voraus binden wollte, schwieg ich mich lieber ganz aus" (Hua X, pp. XV-XVI). Este silenciamento dos problemas do tempo compromete de tal maneira a possibilidade de uma cabal exploração dos actos intuitivos já antes encetada por outras vias que, mesmo a respeito das lições de 1905 sobre "Wahrnehmung, Phantasie und Bildbewusstsein", se pode encontrar no índice geral da autoria de Edith Stein a observação seguinte do próprio punho de Husserl: "vgl. auch die Zeit-Manuskripte!! wo alles neu bearbeitet ist. Also zusammen durcharbeiten" (Hua XXIII, p. 602).

42 Sobre as relações de fiundação, vide L.U., XIX/1, pp. 414 e sgs, XIX/2, pp. 673-685. A questão da fundação conduz, nas Investigações, ao problema da diferenciação entre objectualidades ideais (categoriais) e reais (sensíveis) a partir dos modos de doação. As Ideias anunciam uma "segunda via" de entrada na fenomenologia, que parta não dos problemas da "expressão e significação", mas do lado da "experiência", um caminho que fora justamente pré-traçado nas pesquisas sobre os actos objectivantes de grau mais baixo: "In der Tat war das der Weg, auf dem die "Log. Unters." in die Phänomenologie einzudrigen streben. Ein zweiter Weg von der Gegenseite her, nämlich vonseiten der Erfahrung und der sinnlichen Gegebenheiten, den der Vf. seit Anfang der 90er Jahre ebenfalls verfolgte, kam in jenem Werke nicht zu vollem Ausdrücke" (Ideen I, Hua III-1, p. 287, Anm.).

43 Que toda esta temática culmine numa "teoria da experiência" apontada a uma "clarificação do lógico" é já uma ideia patente nos textos de 1905: "Ich habe übrigens viel gearbeitet und mit Anspannung aller Kräfte meine Schüller und mich selbst zu fördern gesucht. Bewusstsein, Wahrnehmung, Phantasie-, Bildvorstellung, Erinnerung, Zeitbewusstsein, Urtheil, alles im 
Um texto de Ding und Raum, em 1907, di-lo já claramente: "todos os juízos de realidade [...] retornam a percepções e recordações simples, e referem-se ao mundo, que nesta experiência simples acede a uma primeira doação". ${ }^{44}$ A ideia de uma constituição pré-predicativa, de uma evidência primeira do mundo como horizonte de doação da realidade individual a partir do presente vivo da experiência que é "minha", e de uma forma primitiva do "eu mesmo", como suporte da unidade dessa experiência, tal ideia não está, bem entendido, ainda presente ex professo nos primórdios da fenomenologia e em particular nos desenvolvimentos imediatamente sequentes a essa obra de Durchbruch que são as Investigações. Mas no modo como uma Urteilslehre é já aí reconduzida ao estrato fundante de uma Wahrnehmungslehre está já pré-contido o movimento que, no período derradeiro da fenomenologia, havia de radicalizar o significado dessa fundação e pôr a temática do "mundo da vida" como solo originário para uma genealogia da lógica ou, o que é o mesmo, para uma génese dos actos da esfera do logos e das objectualidades neles constituídas. ${ }^{45}$

Adentro daqueles actos intuitivos que são actos objectivantes de "grau mais baixo", este ponto de viragem em que se exprime decididamente o aban-

Absehen auf eine Theorie der Erfahrung und der Klärung der Logik - das waren im Winter und Sommer die Hauptthemen meiner Vorlesungen [...] und meiner ständigen Forschungen". Husserl an Hocking, 10/8/1905, Briefwechsel, III, p. 157.

44 “Alle Wirklichkeitsurteile [...] gehen zurück auf schliechte Wahrnehmungen und Erinnerungen, und beziehen sich auf die Welt, die in dieser schliechten Erfahrung zu einer ersten Gegebenheit kommt". Hua XVI, p. 7 (subl, nossos).

45 Manfred Sommer, em Lebenswelt und Zeitbewusstsein, Frankfurt am Main, Suhrkamp, 1990, expõe a tese de que o modo como a problemática do Lebenswelt se manifesta nas décadas anteriores à sua explícita irrupção (o que ele designa como "Gottinger Lebenswelt") a partir dos anos vinte ("Freiburger Lebenswelt") é a "Konstitution der geistigen Welt", tal como aparece principalmente na Terceira Parte das Ideias II (Hua IV): "Husserl Abhandlung über die "Konstitution der geistigen Welt" beruht auf Manuskripten, die im wesentlichen zwischen 1913 und 1917 entstanden sind. Und sie enthält nicht weniger als eine erste Phänomenologie der Lebenswelt. [...] Decken Husserls frühe Beschreibungen unter Namen wie "geistige Welt", "personale Welt" oder "kommunikative Welt" thematisch das ab, was später "Lebenswelt" oder "Lebensumwelt" heissen wird" (p. 59). Em contraste com esta leitura, subscrevemos a interpretação de D. Carr de que "[...] Husserl as assembled under one title a number of disparate and in some senses even incompatible concepts" (D. Carr, "Husserl's problematic concept of the Life-World", Husserl, Expositions and Appraisals, Notre Dame, University of Notre Dame Press, 1977, p. 203). O estrato de sentido basilar no conceito de mundo da vida é, na leitura de Carr, justamente o da esfera dos actos intuitivos, e particularmente da percepção: "Much of Husserl's actual description of the life-world at this point [in the Crisis] is simply a recapitulation of the phenomenology of perception with wich readers of the Ideas and the Cartesian Meditations are familiar. The life-world is primarily a world of "things", "bodies". He speakes of the perspectival character of perception, of outer and inner horizons [...]" (p. 206). O estrato fundante para a formação do conceito de Lebenswelt é aquela rubrica que Formale und Transzendentale Logik cirscunscreve sob o título de "estética transcendental" (vide F.u.T.L., Hua XVII, pp. 297, 447-453, 454-458). O mundo da praxis, que Husserl introduz na compreensão do Lebenswelt, é um mundo firmado na abertura primária da cousalidade na experiência. 
dono do paradigma da Abbildbewusstsein e a entrada em seu lugar dos problemas da Zeitbewusstsein por via do tema da Reproduktion está bem expresso num texto-programa supostamente dos anos de 1904-1905. Nele pode ler-se o seguinte:

1) Representação própria (apreensão), intuição imediata.

I. Com presentação (representações próprias presentativas). O agora no agora. O objecto da representação agora, o acto também agora, ambos "presente".

II.Com re-presentação (presentificação) (representações próprias re-presentativas). Representações da fantasia e recordativas: melhor, representações recordativas em sentido alargado. Presente o acto, 0 objecto não-presente. No agora, o não-agora presentificado.

2) Representação imprópria.

I. As representações figurativas (figurativo em sentido verdadeiro, imaginatio em sentido estrito). 1) através de imagens presentativas: na base de percepções; 2) através [de imagens] representativas: na base de representações da fantasia; fazer na fantasia uma imagem de qualquer coisa, da qual não nos recordamos.

II.Apreensão simbólica. ${ }^{46}$

Sublinhem-se desde logo aqueles elementos que são também os mais óbvios:47 (a) fantasia e imaginação (imaginatio, єíkađía) são estritamente

46 "1) Eigentliche Vorstellung (Auffassung), unmittelbare Anschauung. I. Mit präsentation (eigentliche präsentative Vorstellungen). Das Jetzt im Jetzt. Das Objekt der Vorstellung jetzt, der Akt auch jetzt, beide "gegenwärtig". II. Mit Repräsentation (Vergegenwärtigung) (eigentliche repräsentative Vorstellungen). Phantasie- und Erinnerungsvorstellungen: besser Erinnerungsvorstellungen im weiteren Sinn. Der Akt gegenwärtig, der Gegenstand nichtgegenwärtig. Im Jetzt das Nicht-Jetzt vergegenwärtigt. 2) Uneigentliche Vorstellung. I. Die bildlichen Vorstellung (im wahren Sinn bildlich, imaginatio im strengen Sinn), 1) durch präsentative Bilder: auf dem Grund von Wahrnehmungen; 2) durch repräsentative: auf dem Grund von Phantasievorstellungen; sich in der Phantasie ein Bild von etwas machen, dessen man sich nicht erinnert. II. Symbolische Auffassung". P.B.E., Hua XXIII, pp. 139-140.

47 Esta reorganização dos actos intuitivos é obtida ao longo do próprio curso de 1905 sobre os actos intuitivos de "grau mais baixo". Nomeadamente, a parte consagrada à "Phantasie und Bildbewusstsein" (Drittes Haupstück der Vorlesungen aus dem Wintersemester 1904/05 über "Hauptstücke aus der Phänomenologie und Theorie der Erkenntnis") acusa de forma nítida esta evolução e as hesitações de Husserl a este respeito. Assim o $\$ 14$ estatui, na esteira do texto de 1898 e das Investigações: "Wir haben [...] den Versuch unternommen, die Phantasievorstellungen zusammen mit den physischbildlichen Vorstellungen unter den einheitlichen Gesichtspunkt der Imagination zu befassen [...]" ("Phantasie und Bildbewusstsein", §14, Hua XXIII, pp. 28-29). O Quinto Capítulo do mesmo curso abre, porém, com um conjunto de considerações cujo resultado último será a separação entre fantasia e consciência figurativa: "Konstituiert sich wirklich in der Phantasie ein Bildobjekt, durch das hindurch ein Bildsujet angeschaut wird? Ich muss gestehen, dass ich hier immer wieder von ernstem Zweifel ergriffen wurde" (idem, p. 55). Estas hesitações de Husserl em pleno curso de 1905 levam a pôr em dúvida a data do texto 
apartadas, a sua diferença é a que passa pelo carácter próprio (eingentlich) e impróprio da Vorstellung; (b) a Vorstellung que é dita "própria" é agora não simplesmente o ter como presente (a presentação), mas o ter-directo (imediato), ou esse carácter auto-apresentador que atrás contrapusemos ao que denominámos como "hetero-apresentação"; (c) no interior da representação auto-apresentadora ou que é própria se insere a diferença entre presentação e presentificação; (d) a determinação de fundo desta última já não é a da Bildlichkeit, mas a da "Erinnerlichkeit" em sentido alargado. Recordação propriamente dita, expectativa, mas também a fantasia (como consciência não-posicional) são agora reconduzidas à estrutura de fundo da Erinnerung, isto é, à consciência reprodutiva. 4849

Aqui se consagra sob uma forma diversa - mas só agora plenamente inteli-

citado na nota anterior (1904/05). E. Marbach, o editor, apoiou-se certamente nas indicações do próprio Husserl. Mas o modo como ele reescrevia constantemente os seus manuscritos, thes acrescentava novas reflexões e, muitas vezes, os datava por junto, por referência à data primitiva, sem dar conta dessa múltipla estratificação, leva-nos a pensar que as razões substantivas para uma data mais tardia se devem aqui sobrepor ao puro facto de uma certa data estar inscrita nos manuscritos. Seja dito que as assim chamadas Lições de 1905 sobre a consciência do tempo, originariamente o Quarto Elemento Capital deste curso de 1905, não são de nenhuma utilidade para o esclarecimento desta questão quando tomadas na versão que delas deu Edith Stein em 1917, e que foi publicada por Martin Heidegger em 1928. Amalgamando textos que vão desde 1901 a 1917, toda a obra está atravessada por contradições insanáveis. Particularmente a respeito da questão em apreço, é possível encontrar no texto das Lições afirmações tão dissonantes como "Das Gegenteil ist Vergegenwärtigung, Re-Präsentation, als der Akt, der ein Objekt nicht selbst vor Augen stellt, sondern eben vergegenwärtigt, gleichsam im Bilde vor Augen stellt [...]" (texto do ciclo de lições de 1905, Zb., §17, Hua X, p. 41, subl. nossos) e, por outro lado, "Wir wissen, das "vergangen" bei der Erinnerung sagt auch nicht, dass wir im jetzigen Erinnern uns ein Bild machen von dem früheren, und was dergleichen Konstruktionen mehr sind" (texto do período 1907-1909, idem, §29, p. 61).

48 "[...] die Reproduktion kann die Art "blosse Phantasie" oder "Erinnerung" haben". P.B.R., Hua XXIII, p. 477.

49 V.g.: "Man könnte sagen: Eine fundamentale Modifikation verwandelt die Wahrnehmung in Erinnerung, und zwar: Wahrnehmung ist impressionaler Erscheinungsglaube - Erinnerung ist reproduktiver Erscheinungsglaube. [...] Wir hätten nur hinzuzufugen, dass Erinnerung hier zunächst nicht Vergangenheitsbewusstsein zu besagen hätte, sondern gewissermassen das reprodutive Seinsbewusstseins, welche näheren Ausgestaltungen immer dann zulassen mag" (P.B.E., Hua XXIII, pp. 245-246). É na esteira deste conceito lato de "recordação" como consciência reprodutiva de uma outra consciência - com crença, primeiramente (= recordação, expectativa), e sem consciência de crença (= fantasia) - que a expectativa aparece caracterizada pela expressão à partida paradoxal de Vorerinnerung. Esta doutrina só se estabiliza a partir de 1909. Husserl hesitará entre a derivação ora apresentada (percepção-recordação-fantasia) e uma outra que, sob a forma percepção-fantasia-recordação, continua a manter uma sub-reptícia referência a um momento presentador (a fantasia não-posicional) no seio da consciência reprodutiva. Cf. Hua XXIII, pp. 224-225 e a nota 1, em que essa posição é rejeitada: "[...] im Fall der Erinnerung habe ich als Unterlage Phantasie, aber darüber hinaus eine neue impressionale Auffassung [...]" - "Da steck der Irrtum. Wir haben doch nicht 1) Phantasie mit ihrem Phantasiezusammenhang [...], 2) eine dazutretende neue, impressionale Auffassung, sondern die Erinnerung ist durch und durch Reproduktion [...]" (subl. nossos). 
gível - a mesma universalidade e fundamentalidade da percepção que já estivera operante na distinção entre Sache e Bild para a dilucidação da diferença entre Gegenwärtigung e Vergegenwärtigung.

$\mathrm{Na}$ verdade, a fundamentalidade da percepção já não se encontra aqui estabelecida pela circunstância inverosímil de tanto a percepção como a presentificação (enquanto consciência de imagem) se articularem a partir de um momento originariamente presentativo. Em geral, o presentificado não é o não-presente figurado a partir do presente, mas a presença do não-presente enquanto esse "não-presente" designa um outro presente que cai no interior da unidade envolvente do fluxo de consciência. Se algo caracteriza a presentificação é justamente esse facto de ela se não dirigir para o que é constituído como realidade presente, mas precisamente para o que é dado como não-presente, de se "transportar" até ele ou de o ter "agora" como "presença" de um passado (ou também de um vir-a-ser): "a recordação é representação directa do passado, do mesmo modo que a percepção é representação directa do presente. Directa [...]: eu vejo-o "na recordação", "eu sou transposto para o passado"', 50 Porque este "não-presente" diz, assim, respeito a um outro acto presentador pertencente ao mesmo fluxo de consciência, a presentificação está assim indelevelmente referida à percepção, ela é ainda uma sua modificação, mas uma modificação que se faz agora apelando para a forma de fundo da temporalidade da consciência e para os tipos de intencionalidade pelos quais a vida a si mesma aparece precisamente como uma tal corrente temporal. Compreendida a partir do fenómeno da reprodução, a presentificação marca, por isso, a entrada dos problemas mais profundos da Zeitbewusstsein como chave para a dilucidação da estrutura e da conexão entre os actos intuitivos. ${ }^{51}$

\section{Consciência do tempo e subjectividade absoluta}

O significado essencial do conceito de reprodução para uma fenomenologia da consciência do tempo está, pois, no facto de, através dele, por vez primeira se tornar possível uma entrada decidida em toda a complexidade da vida

50 "Die Erinnerung ist direkte Vorstellung vom Vergangen, ähnlich wie die Wahrnehmung direkte Vorstellung vom Gegenwärtigem ist. Direkte"; "[...] ich schaue es "in der Erinnerung". "Ich bin versetzt in die Vergangenheit"”. P.B.E., Hua XXIII, p. 235 e p. 203, respectivamente.

51 Essa conexão reforça-se ainda pela circunstância de só às objectividades temporais, constituídas em efectivas presentações, poder corresponder uma presentificação. Se toda presentificação é uma reprodução, nem toda reprodução é uma presentificação: "Das Urteilen hat einen ganz anderen "Sinn", hat ganz andere Korrelate wie ein Erscheinen von Individuellem. Es hat andere gegenständliche Beziehung: Es geht nicht auf Zeitliches. [...] Reproduziert ist das Gegenständliche nicht, es ist nicht vergegenwärtigt. Es ist eben kein Zeitliches". (P.B.E., Hua XXIII, pp. 329-330). Na sua formulação genérica, a presentificação está descrita na fórmula: $R(P(a))=P_{r}(a), a$ reprodução da percepção de (a) e a presentificação de (a) mostram o mesmo fenómeno (e.g., P.B.E., Hua XXIII, p. 311, Zb., Hua X, pp. 127-128). 
de consciência. Enquanto uma reflexão elementar apenas encontra como ingredientes reais da consciência conteúdos primários, sensações ou fantasmas, e actos de apreensão, que produzem a posição do objecto no presente da percepção ou no presente quase-perceptivo da fantasia, um fenómeno tão simples como a recordação deve permanecer incompreendido na sua estrutura basilar.

$\mathrm{Na}$ verdade, todo o movimento da reflexão husserliana sobre este tema entre os anos de 1907 e de 1911, toda a minúcia descritiva que a sua genialidade analítica põe em marcha numa profusão de manuscritos secos, austeros, mas cada vez mais tocados pelo enigma último da fonte originária de toda a vida subjectiva, tudo isso pode ser posto na conta de uma reflexão que se adentra na estrutura da Erinnerung e a aclara progressivamente nos seus estratos constitutivos. ${ }^{52}$ Não temos aqui de curar do pormenor infindo dessas análises, das suas diferenças subtis e quase infinitesimais, que só um olhar educado na ascese analítica pode surpreender e valorizar. ${ }^{53}$ Temos apenas de nos inserir nesse movimento global da reflexão e mostrar o modo como todos os temas em que se dá essa "translação" das pesquisas "objectivas" (sobre os actos intuitivos de base) para as "subjectivas" (sobre a autoconstituição temporal) se encadeiam coerentemente num percurso uno e impartível. O desiderato último das análises é a recuperação regressiva de todos os estratos de sentido que estão operantes e tornam possível o acto da recordação. A recordação é o ver-directo de algo no seu ser-passado. Ela convoca como que um sobrevoo dos tempos na vida de consciência, o qual só é ele mesmo possível se ela for a unidade de uma disten-

52 Isso pode verificar-se pelo simples compulsar do grosso volume da Husserliana XXIII. O tema maior que cataliza todas as descobertas de Husserl é o da Erinnerung e da Phantasie, e é no quadro de uma exploração da essência da Vergegenwärtigung pela estrutura da consciência reprodutiva que a questão do fluxo da "consciência absoluta" é finalmente introduzida na sua forma amadurecida (a referência à consciência absoluta pode ser encontrada, contudo, já no curso de 1906, Einleitung in die Logik und Erkenntnistheorie, Hua XXIV, p. 420). A questão da percepção ficou parcialmente paralisada num resultado insatisfatório, obtido nos anos de 1904-1905 na confrontação com Meinong e não é ela a mola propulsora das investigações decisivas de Husserl, a partir de 1907-1908, sobre a consciência do tempo. R. Bernet nota que "il n'est donc pas étonnant que la nouvelle analyse de la perception de la temporalité des sons ou de la mélodie n'émerge dans les écrits de Husserl qu'au moment où le problème concernant la conscience de la temporalité des actes intentionnels de la conscience a trouvé une solution satisfaisante, à savoir dans les années 1909-1911" ("La présence du passé", La vie du sujet, Paris, PUF, 1994, pp. 227-228). Acrescente-se que esta questão da constituição da "temporalidade dos actos de consciência" (na consciência absoluta) foi posta plenamente a descoberto pela exploração da Erinnerung e a título de sua estrutura fundante (vide Hua XXIII, Text Nr. 14, pp. 301-312, e os Beilagen subsequentes).

53 Esse trabalho de reconstrução está feito, e excelentemente feito, por John B. Brought, "The Emergence of an Absolute Consciousness in Husserl's Early Writings on Time-Consciousness", Man and World, 3 (1972), pp. 298-326, e igualmente por R. Bernet, Texte zur Phänomenologie des inneren Zeitbewusstsein (1893-1917), Hamburg, Felix Meiner Verlag, 1985, "Einleitung", pp. XI-LXVII. Uma apresentação rápida mas penetrante do essencial da posição husserliana encontra-se em R. Sokolowsky, Husserlian Meditations, Evaston, Northwestern University Press, 1974, pp. 138 e sgs. 
são temporal. Mas esse ver do passado em um acto supõe ele próprio toda uma complexidade de estruturas e de formações de sentido já depositadas, que o movimento regressivo da análise deve aclarar intuitivamente na sua génese constitutiva.

Todas as análises de Husserl se deixam compreender neste movimento regressivo de aclaração progressiva. Ele é o movimento em que a vida de consciência retorna sobre si mesma e se tenta surpreender na sua fonte-primitiva, tenta para si mesma exibir-se na sua última profundidade. E, como nos cumpre mostrar, o que vale aí como último, como o originário, é justamente essa dimensão em que o olhar regressivo da reflexão já é em si mesmo impotente para penetrar. O movimento regressivo vai de formação de sentido em formação de sentido, recua até à posição em que elas se deixam aclarar na sua génese constitutiva até embater numa originariedade que lhe deverá aparecer paradoxalmente como dada, mas dada como um ponto cego, para lá do qual o olhar fenomenológico-reflexivo é já incapaz de remontar. Como zona última de visibilidade que apenas se dá a ver naquilo que dela dimana, é esse limite do ver fenomenológico que vale para ele como o originário. Tal limite não se deixa, contudo, pensar como contingente. Ele não é um limite fáctico, recondutível à natureza específica do método fenomenológico de aclaração. Ele não deixa, por conseguinte, em aberto uma outra possibilidade, para a qual o que ora se dá como limite se mostrasse como algo plenamente apreensível. Tal tipo de dualidades não é, aliás, compatível com os supostos da fenomenologia, que não conhecem qualquer oposição entre a "coisa mesma" e os processos "subjectivos" da sua doação. Na medida em que é o método fenomenológico que abre a própria possibilidade do ver que traz a coisa a uma apreensão, este limite deve ser pensado como fazendo parte daquilo que nesse ver é trazido à mostração. Isto não desfaz certamente o enigma a que a aclaração fenomenológica aqui reconduz. Antes o solidifica. $\mathrm{O}$ apresenta como um enigma que tem o seu fundamento in ipsa res.

Que é, efectivamente, reproduzido na reprodução? Resposta: na reprodução é reproduzida a consciência interna em que o acto de presentação originariamente se constituía; ${ }^{44}$ nesse reproduzir da consciência interna, que pode ser um reconstituir passo a passo ou um ver numa mera fulguração, ${ }^{55}$ nesse recons-

54 "«Reproduktion» ist die Vergegenwärtigung des inneren Bewusstseins. [...] Immerhin brauchen wir ein besonderes Wort für die besondere Vergegenwärtigung des inneren Bewusstseins, und die mag Reproduktion heissen". P.B.E., Nr. 14, "Lebendigkeit und Angemessenheit in der Vergegenwärtigung; Leervergegenwärtigung. Inneres Bewusstsein, innere Reflexion. Prägnanter Begriff der Reproduktion" (1911-1912), Hua XXIII, p. 310.

55 " [...] eine Vergegenwärtigung ist möglich, die eine Leervergegenwärtigung ist, es schwebt mir etwas vor, aber ich habe keine merkliche "Erscheinung" davon [...]. Wir haben also hier Unterschiede zwischen klarer und dunkler Erscheinung, bzw. zwischen vergegenwärtigenden Akten von verschiedener Klarheit und Dunkelheit in der Art des zur Erscheinung Bringens". P.B.E., Nr. 14, "Lebendigkeit und Angemessenheit in der Vergegenwärtigung; Leervergegenwärtigung. Inneres Bewusstsein, innere Reflexion. Prägnanter Begriff der Reproduktion" (1911-1912), Hua XXIII, p. 302. 
tituir que admite graus diversos de clareza e liberdade, o objecto sobre o qual a consciência reproduzida se abria numa presentação reaparece com o carácter de presentificado, ele surge coberto com o "véu" da reprodução. ${ }^{56}$

Em que horizonte penetra este acto da reprodução? Resposta: o acto da reprodução penetra num horizonte de tempo imanente, não tempo das coisas e dos processos reais, mas tempo interno do curso de consciência. ${ }^{57}$ No acto reprodutivo, a vida subjectiva para si mesma aparece tematicamente na forma do temporal; mas o acto reprodutivo não constitui esse horizonte, ele encontra-o antes como uma pré-doação; essa pré-doação mostra-se no acto temporador da reprodução sob a forma de uma corrente de posições temporais contínuas que, implicite, conectam em uma cadeia única acto reproduzido e acto actual de reprodução. ${ }^{58}$ Enquanto modo de acesso ao temporal que se edifica sobre a pré-doação de uma corrente unitária de vivências, o acto reprodutivo aponta, pois, para uma intencionalidade que já se pôs em marcha num estrato mais profundo e sem a qual ele não teria diante de si o horizonte em que penetrou.

Onde é esse horizonte interno constituído? Resposta: o acto reprodutivo encontra a vivência reproduzida como uma unidade temporal no fluxo de consciência; ele pode adentrar-se nessa consciência e fazer ressurgir o seu objecto, presentificá-lo; mas ele pode também voltar-se para a própria consciência interna como uma unidade temporal em constante afastamento, atentar no seu constante recuar mais e mais na profundidade do passado e regredir ao longo dessa cadeia, quase-percorrê-la em sentido inverso até culminar no ponto do agora actual. ${ }^{59}$ Esse agora assim encontrado dimana de uma instância que é, simultaneamente, constitutiva da actualidade do próprio acto da reprodução e desse horizonte de tempo interno em que ele mergulhara e onde encontrara o seu

56 "Auch bei der originären Gegebenheit eines Zeitobjekts fanden wir, dass er zuerst lebendig, klar erscheint, dann mit abnehmender Klarheit ins Leere übergeht. Diese Modifikationen gehören zum Fluss. Aber während diesselben Modifikationen eben in der Vergegenwärtigung des Flusses auftreten, treten uns da noch andere "Unklarheiten" entgegen, nämlich schon das "Kläre" (im ersten Sinn) steht wir durch einen Schleier gesehen, unklar da, und zwar mehr oder minder unklar usw". Zb., Hua X, p. 48 (1917).

57 "Das Wesentliche der Art von Reproduktionen, die Erinnerung und Erwartung heissen, liegt in der Einordnung der reproduzierten Erscheinung in den Seinszusammenhang der inneren Zeit, der abfliessenden Reihe meiner Erlebnisse". Zb., Hua X, pp. 59-60 (1907-1909).

58 "Es ist also in jeder Vergegenwärtigung zu unterscheiden die Reproduktion des Bewusstseins, in dem das vergangene dauernde Objekt gegeben, d. h. wahegenommen oder überhaupt ursprünglich konstituiert war, und das, was dieser Reproduktion als konstitutiv für das Bewusstsein "vergangen" [...] anhängt. [...] Das Ganze wird reproduziert, nicht nur die damalige Bewusstseinsgegenwart mit ihrem Fluss, sondern "implicite" der ganze Strom des Bewusstseins bis zur lebendigen Gegenwart". Zb., Hua X, p. 54 (1907-1909).

59 "Aber wenn ich auch nicht den Gesamtinhalt des Bewusstseins erneuem kann, kann ich nicht vielleicht eine Linie verfolgen, herausgegriffen aus dem breiten Strom der Zeit und der sukzedierenden Wahrnehmungen? [...] Ich verfolge, was ich Schritt für Schritt wahrgenommen habe, bis zum Jetzt, und hier besteht doch Kontinuität. [...] Eine gewisse Objektivierung der Zeit ist da vorausgesetzt”. Zb., Hua X, p. 197 (1904?). 
objecto em constante regressão. $\mathrm{Na}$ intencionalidade que recua ao longo da cadeia até ao ponto vivo de actualidade é posto, assim, a descoberto o fluxo de consciência continuadamente constitutivo do agora e da sua declinação, ele é exibido como o verdadeiro locus da génese do temporal. ${ }^{60}$

Que é, agora, este fluxo de consciência? Resposta: este fluxo é o surgir originário do tempo, a perpétua irruptividade do agora na sua diferença com um "já-não", o recuar do agora que está apontando para um "vir-a-ser" e, nesse retirar-se, o traz à eclosão; essa consciência é a generatividade incessante do tempo, o lugar do seu fluir. ${ }^{61}$

Pode essa consciência, na qual o tempo e a posição temporal de todas as vivências se constituem, ser ela própria "coisa" ou "processo" aparecendo no tempo? Resposta: o ver fenomenológico vai para o que se constitui como agora e como passado, porque, para ele, ver é objectivar, pôr-diante na captação evidente, e só o que está fixado e individuado no tempo se deixa assim surpreender; mas, em si mesma considerada, a consciência ultimamente constituinte do tempo e da inserção da vivência no tempo é perpétua actualidade, ela é presente que não passa, que não tem individuação, quer dizer, uma qualquer duração no tempo e a fixidez de uma posição temporal. ${ }^{62} \mathrm{Na}$ sua radicialidade, a vida sempre se articula no modo do presente, e de um presente que nunca devém ele próprio passado; o lugar último de toda a (auto) constituição e (auto) objectivação não é, pois, ele mesmo algo objectivável, encontrável como temporalidade decorrida. ${ }^{63}$ Esse presente permanente não se determina, contudo, como um presente de pura imobilidade; ele é a proto-simultaneidade das fases que põem o agora em unidade com um mesmo-agora-passado e um ainda-não, e a proto-fluxão que incessantemente muda o agora num já-não, e o ainda-não num novo agora. ${ }^{64}$ Em si mesma considerada, essa consciência última é, assim, aquilo a

60 "[Wir fanden:] 1. Der Fluss des "Bewusstseins". 2. Die präempirische "Zeit" mit Vergangenheit, "Jetzt", Nachher; und das präempirisch "Seiende", das dauernde und sich verändernde. 3. Die Stufen des empirischen Seins, des Seins der Erfahrung [... “. Z Zb., Hua X, pp. 286-287 (1907-1909).

61 "Das zeitkonstituierende Kontinuum ist ein Fluss stetiger Erzeugung von Modifikationen von Modifikationen. Vom aktuellen Jetzt aus, der jeweiligen Urimpression u, gehen die Modifikationen im Sinn von Iterationen, aber stetig vorwärts, sie sind nicht nur Modifikationen in Beziehung auf $\mathrm{u}$, sondern auch der Reihe nach Modifikationen voneinander in der Reihenfolge, in der sie verlaufen". Zb., Hua X, p. 100 (1916).

62 "Im ursprünglichen Fluss gibt es keine Dauer. Denn Dauer ist die Form eines dauernden Etwas, eines dauernden Seins, eines Identischen in der Zeitreihe, die als seine Dauer fungiert". $Z b$., Hua X, p. 113 (data indeterminada).

63 "Einheit ist Einheit der Objektivation, und Objektivation ist eben objektivierend, aber nicht objektiviert. Alle nicht objektivierte Objektivation gehört in die Sphäre des absolutes Bewusstseins". Zb., Hua X, p. 286 (1907-1909).

64 "Terminologisch können wir zwischen fluxionalen Vor-Zugleich und impressionalem Zugleich von fluxionen scheiden. [...] Von einer Zeit des letzten konstituierenden Bewusstseins kann nicht mehr gesprochen werden. Mit den Urempfindungen, die den retentionalen Prozess 
partir de que o tempo jorra, mas um "a partir de" que não é para o olhar fenomenológico uma posição em que ele próprio se possa instalar; a consciência última ou absoluta - e é justamente daí que ela retira esse título - só a partir do que dela provém pode ser ela própria "vista", mas vista aí como um punctum cacum, como a irruptividade incessante da vida que no seu devir presente para si mesma se plasma como tempo, e a si mesma aparece como unidade do temporal. 65

Tais são, em traços largos, os momentos que escandem a reflexão de Husserl da Vergegenwärtigung até à consciência absoluta, e tal é o enigma final que a baliza, se bem que não como enigma tenha sido tematizado. Como Rudolf Bernet incisivamente notou, vista a partir do seu núcleo mais primitivo, "[...] uma reprodução de um acto é sempre a reprodução da consciência absoluta pela qual esse acto foi constituído". ${ }^{66}$ Diríamos apenas que o "foi constituído" não se diz propriamente da consciência absoluta, que não é nem processo nem alberga dentro de si qualquer coisa como um "passar" ou um distender-se de fases no tempo, em que só uma seria de cada vez "real". Ora isso significa que, tomado na sua raiz, todo o fenómeno da reprodução em sentido lato é um "encaixe" de consciências em consciências, vida que incessantemente faz apoio sobre si mesma, a si mesma se retoma, se refere, e que só encontra os seus objectos através dessa densidade de uma autopresença cuja parcelaridade se dá sempre sob o pano de fundo da totalidade. É justamente esse constante auto-referimento da vida que faz aparecer o tempo como o fenómeno da sua relação a si. Ele é o horizonte em que se plasma esse originário estar em conexão consigo mesma. Daí também o paradoxo que se desenha no termo deste movimento regressivo pretendendo pôr a descoberto todos os estratos da vida de consciência a partir do fenómeno da reprodução: a profundidade última da vida está "para lá" do tempo como sua fonte primitiva, como o lugar onde dele há consciência, mas esse "para lá" só é contudo visível a partir da sua relação à constituição do

einleiten, konstituiert sich ursprünglich die Gleichzeitigkeit etwa einer Farbe und eines Tones, [...] aber die Urempfindugen selbst sind nicht gleichzeitig, und erst recht nennen wir die Phasen des fluxionalen Vor-Zugleich nicht gleichzeitig Bewusstseinsphasen, ebensowenig wie wir das Nacheinander des Bewusstseins eine Zeitfolge nennen können". Zb., Hua X, p. 78 (1911).

65 "Der Fluss des immanenten zeitkonstituierenden Bewusstseins ist nicht nur, sondern so merkwürdig und doch verständlich geartet ist er, dass in ihm notwendig eine Selbsterscheinung des Flusses bestehen und daher der Fluss selbst notwendig im Fliessen erfassbar sein muss. [...] Das Konstituierende und das Konstituierte decken sich, und doch können sie sich natürlich nicht in jeder Hinsicht decken. Die Phasen des Bewusstseinsflusses, in denen Phasen desselben Bewustseinsflusses sich phänomenal konstituieren, können nicht mit diesem konstituierten Phasen identisch sein, und sind es auch nicht". Zb., Hua X, p. 83 (1911). "Es ist der eine, einzig Bewusstseinsfluss, in dem sich die immanente zeitliche Einheit [...] konstituiert und zugleich die Einheit des Bewusstseinsflusses selbst". Zb., Hua X, p. 80 (1911).

66 "[...] une reproduction d'un acte est toujours la reproduction de la conscience absolue par laquelle cet acte à été constitué". "La présence du passé", La vie du sujet, Paris, PUF, 1994, p. 238. 
tempo, a partir do facto primeiro da sua dispersão nos horizontes do temporal. A "subjectividade absoluta" - tal é o nome que para ela surge no $\$ 36$ das Lições ${ }^{67}$ - é algo que só se deixa nomear "[...] a partir do constituído". 68 O que o movimento regressivo aponta como originário só se dá a ver no e pelo originado, ele é uma fonte última que só se mostra enquanto se subtrai ao olhar, enquanto o olhar regressivo a tem diante como seu ponto cego e também como seu enigma.

A linha de reflexão que põe a Zeitbewusstsein como fio-condutor para a dilucidação dos actos intuitivos vê-se, assim, conduzida a este resultado: primeiro, a diferença entre presentação e presentificação assenta na autoconstituição de uma corrente temporal na pré-temporalidade da "subjectividade absoluta"; segundo, a constituição de uma tal corrente não é constituição do tempo como um elemento no qual a consciência simplesmente "esteja", mas um tecido de intencionalidades em que a profundidade temporal de uma corrente contínua aberta nas direcções do futuro e do passado aparece como forma do ser para si mesmo da vida de consciência; terceiro, esse aparecer do tempo verifica-se nos actos da reprodução (lato sensu), mas ele não é na reprodução constituído; quarto, a consciência em que o tempo se constitui "antes" de todo e qualquer acto da reprodução (embora este "antes" não tenha ele próprio significação temporal) só se dá como visão do tempo, quer dizer, a partir do que nela se constitui.

O movimento regressivo choca, assim, com um nec plus ultra. Mas, significativamente, o movimento regressivo não põe este "não mais além" como um "nada mais além". O movimento regressivo localiza antes nesse ponto cego para o olhar fenomenológico-reflexivo a forma originária da vida subjectiva, transporta para aí o processo da constituição última do tempo, embora tal absolutez seja justamente o que ele não pode, em aparência, penetrar.

Neste "salto" que põe esta originariedade de uma autoconstituição do tempo está contido o limite do esquema da Bildbewusstsein e a razão de ela não poder ser mais mantida no quadro deste movimento de retorno encetado pela reflexão fenomenológica. De facto, na Bildbewusstsein supõe-se, como foi apontado, não um processo de transposição no tempo, um estar para si mesmo presente na distância temporal, mas apenas uma representação do ausente a partir de um constituir presentador, seja na imagem "física", perceptivamente fundada, seja no "fantasma", enquanto conteúdo posto como agora-presente. O suposto basilar da Bildbewusstsein era que a consciência estava, de cada vez, encerrada em um agora actual. O passado não era, como tal, trazido até o presente ou, dito inversamente, o presente não se desdobrava até uma reprodução do passado porque, justamente, ele, enquanto passado, era suposto não estar já disponível para uma doação directa. A vida de consciência entendia-se, assim, como fechada nos quatros muros da sua actualidade momentânea. Ela não 
dominava o tempo nem vivia na sua confluência. Antes se encerrava no tempo e apenas alcançava um intuir do não-presente a partir do que nela de cada vez se constituía no presente. Ora este suposto que atravessava a teoria da Bildbewusstsein era também o suposto de que o tempo não era da consciência, mas que a consciência se encontrava antes no tempo, um tempo que só podia ser, portanto o tempo objectivo e mundano.

O modelo da Bildbewusstsein para a determinação da essência da presentificação significava, assim, a presença recalcitrante de um suposto naturalista no interior da fenomenologia incipiente. A progressão de Husserl entre 1898 e os anos de 1907-1911 a propósito dos actos intuitivos de "grau mais baixo" é precisamente o lugar onde se produz a libertação da fenomenologia relativamente à sua primeira aprecepção naturalística da consciência. Essa libertação exprime-se, tecnicamente, no afastamento do tema da Bildbewusstsein e na sua substituição pelo da Reproduktion. Por aí desponta, como vimos, uma compreensão radicalmente diversa do estatuto da Vergegenwärtigung. Mas, ao mesmo tempo, porque a Reprodktion-Erinnerung conduz à Zeitbewusstsein e à descoberta do fluxo da "subjectividade absoluta", essa rectificação da doutrina dos actos intuitivos despoletará também uma compreensão não naturalística da consciência que se virá plasmar, desde 1907, na apresentação da fenomenologia como uma filosofia transcendental.

\section{Resumo}

En partant d'un texte de 1898 sur Phantasie et bildliche Vorstellung, nous montrons la première décision de Husserl qui choisit d'interpreter la Vergegenwärtigung sur le modèle de la conscience d'image. Nous montrons ensuite la façon dont Husserl vient à corriger son premier point de vue et cerner de plus près l'essence de la Vergegenwärtigung comme Reproduktion.

Les implications de la nouvelle doctrine de Husserl se révèlent surtout dans l'intervention des problèmes de la conscience intime du temps comme lieu de compréhension de la structure phénoménologique des actes intuitifs sensibles. Le problème qui se profile à l'horizon deviendra celui plus général de la Selbstkonstitution du flux de conscience. 